E.I. du Font de Nezours \& Co. Explosives Department Atomic Energy Division Wilmington, Delaware

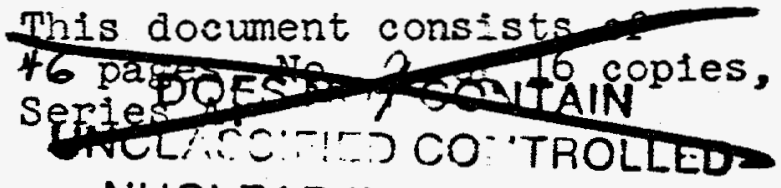
NUCLEAR IIVORMATION

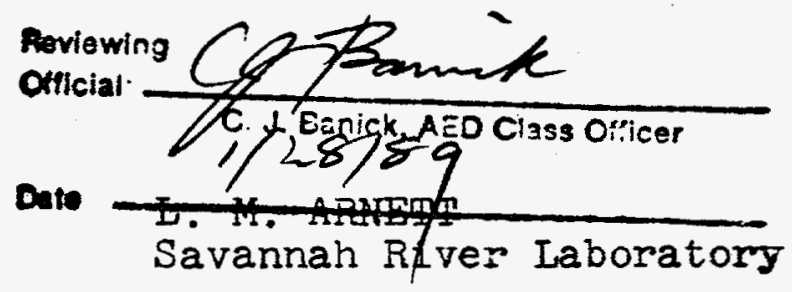

1 - I. M. Arnett $(5 / 2 / 4--793)$

2 - M. H. Wahl - C.X. J. Wende

3 - J. W. Croach - P. I. Permar

4 - C. C. MicBride - A. S. Ferrara

5 - B. I. Richards

6 - B. W. Dunnineton

7 - TIS File

8 - R. M. Evans - B. F. Mackey

O- H. Worthincton - D. F. Babcock

11 - N. F. Spraggins - R. R. Herries

12 - R. E. Pisher - E. $\Xi$. Hayes

13 - J. E. Cole - M. E. Smith

14 - J. B. Tinker - M. S. Bloomsburg

15 - K. W. Wllett - T. C. Evans P. M. Allen

16 - W File

June 22,1956

\title{
ROUGH DRAPT OF TECHNICAL DATA SUMMARY COVERING PREPARATION OF INITIAL MARK IIIA FLATES BY EXTRUSION CLADDING
}

The subjoined rough draft included several sections of a proposed Technical Data Summary covering the preparation and fabrication of the outer Mark IIIA plate and the plain Mark IIIA plate by extrusion cladding at SRP.

Will you please correlate this draft with the informat:on to be supplied by the Laboratory in preparing a Technical Data Summary on the fabrication and testing of an interin liark IIIA fuel assembly.

Attached to this memorandum is a working schedule of dates for the completion of this test program.

The attached draft is not be construed as directions for operating or manufacturing, but is issued for information and to elicit comments and suggestions.

\section{Clastifleation Cancellod/Chanew TO UNCLASSIFIED}

By Authority of

\section{1.}

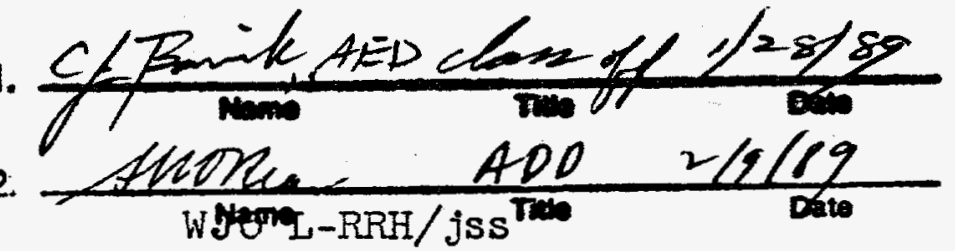

ATOMIC ENERGY DIVISION

Technical Division
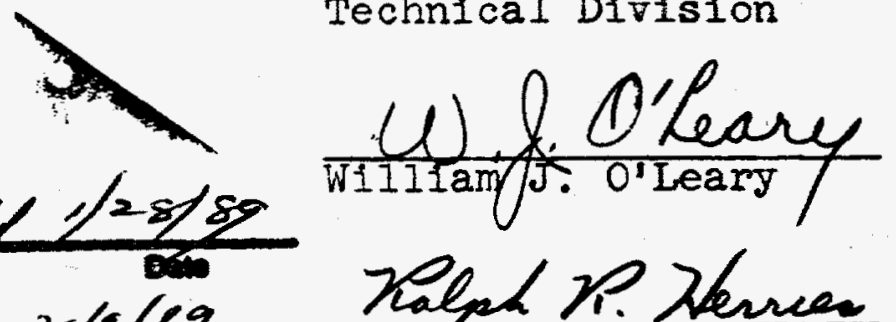

Ralph R. Herries 


\section{DISCLAIMER}

Portions of this document may be illegible in electronic image products. Images are produced from the best available original document. 


\title{
GOAIS FOR EXTRUSION CLADDTIG OF PLATES
}

\author{
BMI - Data on end plugs .............. Julz 1 \\ BMI - Data on extrusion speeds ......... August 1 \\ Building alterations (320M) ......... Prion July 15 \\ Tools delivered . . . . . . . . . . July 15 \\ Set-lp tools - Heat tests - Dry runs ....... August 1 \\ Ten runs with steel cores - narrow 3 A design ... . August 7 \\ Nickel-plated 5-ft. length. No end plugs. \\ Temp. tools, $1025-1050^{\circ} \mathrm{F}$
Container, $\left(\begin{array}{c}552-566^{\circ} \mathrm{C} \\ 552-566^{\circ} \mathrm{C}\end{array}\right)$ \\ core, $\quad 975^{\circ} \mathrm{F}\left(525^{\circ} \mathrm{C}\right)$ \\ Core speed - 4-10 ft/min. \\ Ten runs with steel cores - narrow 3A design . . . August 15 \\ Nickel-plated 14-ft. length. \\ 5 runs, integral end plugs. \\ 5 runs, leading end plug of stee 1 attached. \\ Conditions as above or revised from experience. \\ Changes to die and tip, if necessary ...... Auzust 15 \\ Ten runs full length $U$ plates - $3 A$ narrow design \\ evaluation to be made currentiy wits extrusion . A Auzast 15-20 \\ Receive mandrel tip and die for wide plate.... Seftember 15 \\ Ten full length $U$ cores, wide $3 A$ design..... October 1
}

\section{DISCLAIMER}

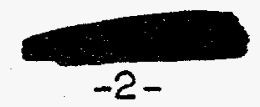

This report was prepared as an account of work sponsored by an agency of the United States Government. Neither the United States Government nor any agency thereof, nor any of their employees, makes any warranty, express or implied, or assumes any legal liability or responsibility for the accuracy, completeness, or usefulness of any information, apparatus, product, or process disclosed, or represents that its use would not infringe privately owned rights. Reference herein to any specific commercial product, process, or service by trade name, trademark, manufacturer, or otherwise does not necessarily constitute or imply its endorsement, recommendation, or favoring by the United States Government or any agency thereof. The views and opinions of authors expressed herein do not necessarily state or reflect those of the United States Government or any agency thereof. 
SECIION I - INTRODUCTION

This Tecinical Data Summary comprises the technical information tha: has been developed to date for the freparation by extrusion claciling of the outer plate (Fszure 1, Drawing MDXI-437) of the contemplated Mark IIIA fuel plate bundle.

The Mark IIIA fuel bundle is designed to produce plutonium at higter fower levels than is possible with the Mark I or Mark VII assemblies. The Mark IIIA anc Mark $V$ des' concurrextiy for the same purpose. The information, however, on the Mark IIIA design is at present far more complete than for Marz $V$, and equipment for producing Mark IIIA in test quantities is Eiready avallable. The purpose of this Technical Data Sumrary is to hare available the facilities for cladding, by an apparentiy attractive process, a Mark IIIf plate.

The approach to preparing Mark IIIA fuel elements has been threefolc, name $y$, (a) by hot step-pressing (DPSTM-700-III, 1/30/56; DPSM-700-IIIA, in preparation); (b) by Iuid pressure bonding; and $(c)$ iy extrusion cladding, which is the subject of this sumary. From the data assembled in DPW-56-197, April 10, 1956, the extrusion cladding approach is decisively the most economical. It appears that the last process is the simplest and most practica: of the three.

SECTION II - SUMMARY

The Mark IIIA fuel element is an assembly of natural uranium plates des -gned with a ratio of surface to volume that is abolit 2.5 times that of the standard slugs in a quatrefoil. The assembly is designed for operation with a coolant flow of about 250 spm and at a pile power of 1800 to $2000 \mathrm{MW}$. The assembly contains five aluminum-clad plates (Including two different core sizes anc three different cladiing cross-sections) assembled in an aluminum housing tube, and is a direst replacement of the quatreroils.

In crder to establish at the earliest possible time the workinz data and know-how on which to build a manuifacturing process to extrusion-clad Mark IIIA plates, the outer ribbed and plain Mark IIIA plates (PIss. I \& 3) will be extrusion-clad and bundled in a Mark III "B process tube" for evaluation and test. It is not expected that Mark IIA process tubes in which to put the Mark IIIA plates will be avallable until october, so it is desirable to use the expedient of employing Mark III tubes terporarlly in order not to delay the test program.

\section{SECTION III - ADVANTAGES OF EXTRUSION CLADDING PROCESS}

The extruston cladding process for plate fuel elements appears more attractive than step-pressing, fluid pressure bonding, roil claciing, or other methods of sheathing ior the following reassas:

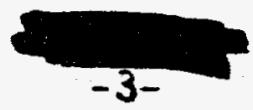


a) No preformed sheaths are required. These are an expensive item with a long delivery; they require careful handling, expensive storage, special cleaning, and involve difficult inspection procedures, especiaily for the internal bore.

b) No assembly problem exists. With preformed sheaths, both cores anc sheaths must be segrezated into different dimensional groups within the manufacturing tolerances set for each, because a core at the maximum tolerance will not fit into the smallest I.D. sheath; under the reverse circumstances, too loose a fit occurs that results in seams and laps in the sheath.

c) The sounciness of the cladding over the core is better assured by bonding it to the core as the aluminum is extruded, instead of extruding separately a hollow sheath over a fixed mandrel that could be scoring or gouging during the process.

d) With extrusion cladding the sheath thickness can be varied at will, and reduced to the thinness desired from the physics riewpoint, while maintaining the same integrity of metal. Cther things belng equal, an equally thin preformed sheath could not in practice survive the necessary handling.

e) Stronger bonds have been obtained more consistently by the extrusion cladding process than by other cladding methods.

f) Extrusior cladding Involves less steps, fewer mechanical operations, and is all-around a more rapid cladding method than other processes.

g) All of the foregoing have shown in cost esimation that extrusion cladding will develop an appresiable saving in fuel element costs.

SECTION IV - DESCRIPTION OF THE FUEL ASSEMBIY

A. The Assembly

The Mark IIIA assembly contains iive plates of natural uranium clad with aluminum in an aluminum housing tube. Drawings of the Mark IIIA plates, housing tube, and assembly are shown in DPSTM 700-IIIA (in preparation at SRI). Since IIIA housing tubes are not expected to be avallable for the initial extrusion-clad iranium piates, this summary is based on employing for the interim assembly a Mark III process tube, and fitting into this an edge-planed Mark IIIA plain plate held between two Mark IIIA outer ribbed plates, which in turn are spaced away from the "Dees" of the Mark III process tube by aluminum shims. This interim assembly is shown in cross-section in Figurs 2 , and will contain three instead ô five plates.

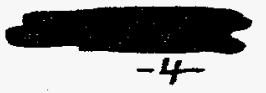


The assembly is made of tiree-piece top and zcttom fittzazs, a housing tube called a "B process tube," anc a bundie =: three uranium plates. Tre plates are supported by the bottom fitting and are stabilized lateraliy is the chorial membranes ("Dees") of the "B process tube". Coolant channels are maintained by ribs trat are an integrai part of the aluminum cladding of the outside plates.

B. Active Components

The fuel for the Mark IIIf assembly is a bunjie of five plates of natural uraniur clad in aluminum, as describej in DPSTM 700-IIIA (in preparation at SRI). The fuel, howerer, for the interim Mark IIIA assembly described in this Su-ary will be three plates (instead of five) of natiral uranizclad in aluminum. The dizensions and specifications foz these plates are shown in Figures 1 and 3 (Dzawing Nos. MDXI-437 and MDXI-439). The overall thickness of the Fites and the specifications for straightness are critical for loading the plate bundle into the process tuje.

Since it will be necessary in this interim assembly to employ a Mark III "B process tube," into which the unriobed Mark IIIA plain plate does not fit until modified, it is necessary to mill off the beveled edges of tiee cladding shown in Figure 3 to produce tive rectangular cross-section or this clad plate shown in Figure 4. The small, riobed Mark I=-A plates shown in Figure $I$ can be fitted into tre Mark II: "B process tube" without necessity for modification.

\section{Structural Components}

1. Housing Tube

It is not expected trat Mark IIIA housire tubes wiI: be available until Octoier, so a Mark III " 3 process tije" will be used as houstng tube; this is show in Figure 5 . It is an extrusion of 635 aluminum with two chordec

membranes. The distance between these meribranes ans the membrane thickness of the tube are critical dimensions. The nominal clearance between the bundle of fuel plates and the membranes of the tube is 0.011 incin. This clearance is increased to about: 0.026 -inci over the ribs nearest the edges of the plates when the "Dee" sections of the tube are evacuated to about 28 incres of mercury.

During reactor operation the "Dee" sections are at $\equiv$ higher pressure than the coolant channels, and this differential pressure causes the membranes to dejlezt toward the plates.

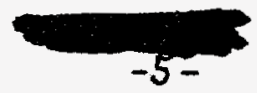




\section{$>$}

Since the fuel bundle will contain only three instead of five Mark IIIA plates, and since the housing tube is a Mark III "B process tube," two aluminum shims are required to fill up the remaining space in the assembly. These shims will be used one on each stae of the plate bundle between the outer ribbed plate and adjacent "Dee" membrane; their dimensions are shown in figure 6, and their position in the assembly is shown in Figure 1 .

PIugs are welded into the "Dee" sections of the "B process tube" as shown in Figure 7 .

A solid plug, shown in Figure 8 , is weided into the bottom of the tube and machined to proside a square surface for properly seating the bottom fitting. Each of the bottom plugs is drilled and reared for a press fit with a stainless steel sleeve, Figure 9, that provides a leak-free connection from each "Dee section of the tube to the bottom fitting.

After the chips and cutting o1l are completely removed from the tube, the pre-drilied top pluss, Figure 10, are welded in place. The holes in the top piugs provide a means of evacuating the tube for loading, and permit coolant to enter the "Dee" sections during pile operation.

2. End Plings

In order to assure an adequate cladding at each end of the uranium core, and in order to assure that there is sufficient metal in this end cladding $\neq 0$ be able to weld thereto aluminum end fittings without alloying or thermalig changing the metallurgical siructure of the adjacent uranium core, it is required that the core have terminal end plugs preferably made of aluminum. These end plugs must be approximately of the same dimensional cross-section as the core, and a minimin of one inch long to provide sufficient metal for a weldment to the end fittings. A long end plug can easily be cut of $f$ to the desired length. The end plugs must be attached firmly to the ends of the uranium core in order to prevent deterioration of the joint by corrosion, to withstand rough hardling, and to support the weight of the core. Both end plugs may be the same to avoid special front and rear handling of cores. A drawing of a typical end plug, showing the preferred methods of dovetailing to the end of a uranium core, whether integrally extruded or attached, is shown in Figure 11 .

The most recent data from Battelle show that none of the common aluminum alloys have sufficient hot strength to resist "pinching of $f^{\prime \prime}$ when the plug is attached to the core and the assembly is subsequently subjected to extrusion cladding. This is particulariy true of the

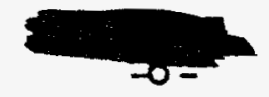


leading end plug; with the trailing end plug no difficulty is encountered, because the extruding aluminum follows the core through the die forming a bonded end plug, whether or not a separate end plug had initialiy been fastened to the core. When the leading end plug is made of steel or of metal with a higher hot strength than common aluminum alloys, no trouble is encountered; the aluminum cladding is then continuous over the core and end plug.

For this reason, the end plugs initially employed for this feasibility test wili be made of carbon steel or of "SAP" (aluminum containing $12 \mathrm{v} / 0$ to $19 \mathrm{v} / 0$ aluminum oxide). Battelle is continuing, however, to look into other alloys of aluminum to see if somethin: more suitable than steel can be found, and to develop integrally extruded aluminum end plugs. A "pusher mecranism" (a mechanical device incorporating two flat shoes to grif the core and push it about one-half to one inch out of the mandrel tip into the flowing aluminum) is being designed and built by the Mechanical Development Laboratory. This pusher will be placed at the entry side of the die block, so as to grip and push the core as close to the leading end as is practical. When this is operating satisfactorily, attached end plugs of carbon steel or of aluminum alioy will not be used, but integral end plugs will be extruded with the core with the help of the pusher. Consequently, Items 20 to 30 inclusive in the Flow Sheet will be eliminated with integral end piuss.

In order, however, to avoid last-minute delays in proing the feasibility of cladding full-length cores, planning has proceeded on using attached end plugs.

3. The Top Fitting

This is essentially as described in DPSTM 700-III, page III-3, except as may be modified for the higher flow rate of the interim assembly.

4. The Bottom Fitting

This is essentially as described in DPSTM 700-III, page III-4, but may require modification for the higher flow rate of the interim assembly.

SECTION V - ASSEMBLY

This is essentialiy as described in DPSTM 700-III, page $V-I$.

The principal exceptions are: a) In order to assemble the two sizes of plates in the Mark III "B process," it is first necessary to remove from the center plate (Figure 3), by dry machining, the beveled aluminum cladding to change the crosssection of the plate to that shown in Figure 4. This is 
necessary in order to make the center plate fit inside the "B process tuce". b) In order to take up the excess space between the two outer plates (Figure I) and the chordal "Dees" of the "B process tube", it is necessary to use two of the aluminum shims shown in Figure 6 . These shims are required for this initial feasibility test because only three of the eventual five plates $\mathbb{1 1}$ be employed in the assembly.

SECTION VI - DISASSEMBLY

This is essentially the same as described in DPSTM 700-III, page VI-1.

\section{SECTION VII - SEPARATIONS}

It is intended to transport these Mark IIIA fuel elements to the 200 Areas as full-length elements. No cutting, with attendant contamination by radioactive products, is contemplated.

\section{SECTION VIII - FABRICATION OF ACTIVE ELEMENTS}

This interim Nark IIIA fuel element will consist of three individual cores of natural uranium 13 feet, 6 inches long and 0.180 inch tisick when clad. The cores will first be coated with nickel 0.000 inch thick and then bonded in an aluminum sheath of 0.030 inch wall thickness by extrusion cladding. Aluminum end plugs maj be integrally extruded with the cladding, or may be attached to and bonded to each core prior to cladding; information needed to firm up this detail is being developed by Battelle, and will be available by July 1. The end closure is obtained by weiding aluminum end fittings to the bonded end plugs. The width and rib-to-rib height of the finished plate are controlled by the extrusion die.

Handling the plates between operations is a problem requiring special care. The high density of the material and the thin section reduce the rigidity of a plate to the extent that it must be supported at many points to prevent bending. Whenever possible, plates should be handled with the width in the vertical position to winimize the possibility of bending.

The process information is presented under the following headings:
A. Process Description
B. Process Data (Flow Sheet)

A. Process Description

1. Procurement of Components

Jranium Cores

The cores are rolled and machined by the Superior Steel Corporation. The experimental quantities of uranium plate required for this program will be 
beta-transformed at Atlas Steels, Itj. In Canaia. For production quantities, it will be necessary to provide heat-treating facilities, preferably at the site where the plates are fabricated. The cores should be straightened and machined to specified dimensions by the vendor.

The cores are prepared as follows: Rectangular ingots $10-1 / 2^{\prime \prime} \times 4^{\prime \prime} \mathrm{X} 38^{\prime \prime}$ welghing about 1100 pounds each are cast at Flif , and are slabbed at FMPC to $101 / 2^{\prime \prime} X$ $1-1 / 2^{\prime \prime} X 103^{\prime \prime}$. They are then sent to Superior Steel Corporation where they are machined to obtain fiat surfaces and to remove surface imperfections. The slabs are creheated at $1150^{\circ} \mathrm{F}$ for 30 minutes in a $35 \%$ $\mathrm{LI}_{2} \mathrm{CO}_{3}-65 \% \mathrm{~K}_{2} \mathrm{CC}_{3}$ bath, cooled for aicut 60 seccras, and roligh-rolles at around $1075^{\circ} \mathrm{F}$ to reduce the inickness from about $1-1 / 4^{\prime \prime}$ to $0.35^{\prime \prime}$ in 5 passes. Fre strip so produced cortinues from the roughing mill to the finishing stancs, where it is reduced in 3 more casses to the thickness range $0.180^{\prime \prime}$ to $0.190 "$ " After croppins and cutting to length, the sheets are pickled, rinsed, and dried with forced dry air.

The resulting sheets 15 feet long bs 10 inches is de are then shipped to Atlas Steels, Ito., Wellanc, Ontario, where they are jeta heat-treated by seating for 2 minutes in a salt bath at $1320^{\circ}$ to $1360^{\circ} \mathrm{F}$, coolins in air to $600^{\circ} \mathrm{F}$, and finish quenchirs in water. Immersing in water removes the salt From the heat treating.

The sheets are then returned to Supenior Steel Corporation where they are slit and ecse-machires to the required width. They are then packed and sispped to SRP.

The specifications for the required vare uranilim cores, given in DPST-55-437, are summarizec below:

Density

Chemical Composition Element

Carion

Boron

Iron

Nitrogen

Manganese

Chlorine Silicon (reported as $\mathrm{SiO}_{2}$
equiv.)

Chromium

Nickel

$$
\begin{aligned}
& \frac{\text { Nat'1. } \frac{18.82 \text { Erams/cc rinimum }}{\text { U. with following impurities }}}{\text { Quantity, ppm }} \\
& 150-700 \\
& \text { C. } 25 \max \text {. } \\
& 150 \text { max. } \\
& 100 \text { max. } \\
& 25 \text { max. } \\
& 20 \max \text {. } \\
& 58 \max . \\
& 65 \max . \\
& 65 \text { max. }
\end{aligned}
$$




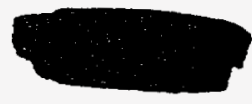

Dimensions (See Figures 12 and 13)

Length $\ldots \cdot .172$ inches $\pm 1 / 2$ inch.

(as received)

Width ... 2 widths required:

2.460 inches \pm 0.005 inch for ribbed plate.

2.940 inches $\mp 0.005$ inch for plain plate.

Sides are machined; edges are broken with file.

Thickness $\cdot 0.185$ inch \pm 0.005 inch.

(as recelved)

End Design.. This has not yet been established, and awaits data from BMI. It is known that trailing end plugs can be integrally extruded with the several end designs shown in Figure 11, but there are still insufficient data on leading end plugs to decide on the best of these for a leading end design. For this feasibility test, "SAP" end plugs will probably be used.

Surface . . . The plates are inspected visually and rejected for surface defects which would interfere with bonding. Surface is as-rolled.

Structure ... An equiaxed beta-transformed structure is required.

Straightness

Camber . . . $0.030 \mathrm{inch} / 2$ feet max. Max. of 0.060 inch (saber curve) in 14 feet of length.

Bow.... 0.015 Inch/foot max. Not more than ore 0.015 inch bow for each foot of length. Max. of 0.060 inch in 14 feet of length. Straightness of plates is important to prevent excessive friction or jamming of the plates in the mandrel tip and die during extrusion cladding.

Straightening. Plates that do not conform to the above requirements will be stretch-straightened.

Handling . . . In order to prevent bending and to maintain the plates as straight as possible at all times when being transferred from one operation to another, they will be placed In channels of aluminum or other suitable material. When not being transferred, the plates whould be laid on tables. 


\section{Aluminum Sheaths}

Each plate will be sheathed with aluminum by extrusion cladding. One billet of 1100 or of M-329 aluminum, about 6-5/8 inches in diameter by 9 inches long, is required to clad and to furnish bonded end plugs to each plate. Since in the extrusion-cladding process the sheath w1ll be formed over the core, there are no dimensions for the sheath as such. The desired dimensional tolerances on the two different clad plates are shown in Figures $I$ and 4.

\section{Nickel Plating of Cores}

The core is coated with nickel in an electroplating process that includes five main steps: (1) degrease, (2) acid pickle, (3) anodic etch, (4) acid etch, and (5) electroplate. Cores are placed in stainless steel racks for handing during cleaning and plating, and the rack serves as a "thief" during plating to minimize build-up of the nickel at edges and corners. Two or three cores may be plated in a single rack as long as each core is encircled by a thieving frame. Rack design must permit movement of the contact points at least once during the plating cycle, to prevent bare spots at the points of contact.

Adherence of the nickel plate to the core, and the subsequent diffusion during bonding are dependent upon obtaining a clean uranium suriace for plating. The racked core is degreased to remove any oll remaining from the machining operation (to obtain metallographic samples, for end design, etc.), and is pickled in hot nitric acid to remove rolling scale. An anodized layer is then produced on the uranium surface by electrolytic treatment, and is subsequently removed by etching in a nitric acid solution.

Experimental results have shown that roughening the uranium surface before plating is an important step in achleving reproducibly good bond strength. The roughening procedures most successfuliy employed have been (a) dry grit blasting, and (b) anodizing. Recovery of uranium is simpler following the anodizing process, so this is preferred. Anodization and subsequent acid removal of the uranium oxide layer result in a removal of about 0.0015 inch of uranium from each surface of the plate. This treatment insures that electroplating is conducted on a fresh uranium surface. The surface layer of uranium that is removed often contains a high concentration of hydrogen. The total surface layer of uranium that is removed by pickling, followed by anodizing, followed in turn by acid removal of the oxide formed corresponds to a reduction of about 0.003 to 0.004 inch in the core thickness from the as-received condition $(0.184 \pm 0.004$ inch to $0.180 \pm 0.004$ inch).

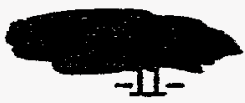


A layer of nickel about 0.0004 inch +0.0001 inch thick is then deposited on the core from a high sulfate bath. With the present rack design the build-up of nickel at the edges is approximately twice the thickness of the layer over the surfaces, and this build-up extends about $1 / 8$ inch from each edge and corner. Since the deposited nickel is relatively porous, the plated cores are dried in hot air to minimize the amount of retained moisture. The temperature and the time of the drying operation must be controlled to prevent oxidation of efther the nickel or the uranium. The high sulfate bath was originally used as a "strike" bath, and the bulk of the nickel was deposited from a modified Watts bath. The Watts bath was discontinued because rinsing the plates in the process water available in the laboratory resulted in contaminated nickel plate. This contamination was caused by the higi calcium content of the process rinse water, and can be eliminated by using delonized water.

Thorough rinsing of the electroplated cores is required to remove acids and salts, and to eliminate contamination of the electroplate.

3. Preparation of Components

The extrusion billets of 1100 aluminum or M-329 aluminum, about 6-5/8 inches in diameter by 9 inches long, must be lightly surfaced by machining dry in order to remove impurities and contaminants embedded in the surface. Since the billets are completely upset during extrusion, and therefore present oxide-free metal continuousiy to the core to be clad, no chemical cleaning is required.

4. Extrusion Cladding

The ground rules agreed upon for using the Watson-Stillman extrusion press in the 320 Building for this extrusion cladding program are (a) that the press shall not be changed or modified in any way that will prevent return to its original condition upon demand; (b) that this extrusion cladding program shall not in any way interfere with production requirements; and (c) that coated (electroplated) uranium cores be delivered to the extrusion press to avold contaminating the 320 Bullding with uranium.

No modification of the Watson-Stillman press is required that would be in conflict with the preceding paragraph. This press does not have an opening extending from the hollow ram back through the cylinder to the outside of the press, so it is impossible to employ the Battelle method of making a fully coaxial extrusion.

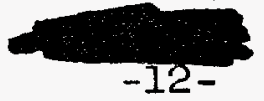


There is, however, no difficulty in employing a rodification of the Battelle approach with the Natson-Stiliman press, in which the billet is forced to make a right-angled turn. This involves the manufacture of a container to fit the present container holder in the 320 Bulding press. This new container will direct the extruding biliet of aluminum through a turn at right angles to the direction of ram movement, to meet and envelope the core which will travel also at right angles to the direction of ram movement. The new contalner will consequently be roughly L-shaped, with the die attached to the right-hand bottom end of the $I$, the core entering at the left bottom end of the $L$ and exiting through the die, and the aluminum billet entering the top of the $L$, as viewed from the back of the press looking toward the die abutment. This is shown schematically in Pigure 14.

As the billet is making effectively a horizontal rightangled turn, it is divided into two streams of aluminum by two portholes and a divider in the bore of the container. Each of the two streams of aluminum is thereby directed into a corresponding annulus formed by the container walls and an internally positioned mandrel. At this stage, there are two streams of aluminum flowing at right angles to the ram movement, and flowing parallel to the core, which is moving also at right angles to the ram movement inside the hollow mandrel which acts both as a core guide and as a separator to prevent the aluminum from making contact with the core at this stage.

The two streams of aluminum now are forced through additional portholes to fan out and distribute the metal as symmetrically as possible around the tip of the hollow mandrel, so that a uniformly advancing sheath of aluminum will be avallable to envelope and bond onto the nickelplated core as the latter emerges from the manarel tip.

Fastened to the exit-end of the container, and spaced 0.040 to 0.100 inch beyond the mandrel tip is the extrusion die. The pressure-temperature-time relationships necessary to weld the portholed streams of aluminum integraliy together, and to bond the aluminum to the nickel-plated core, are developed in this 0.040 to 0.100 inch welding chamber in front of the die. The die then acts as a sizing and shaping suide for the extrusion-clad core. A separate die and mancrel tip combination is required for each different core size; a different die is required for each change in rib height.

Although extrusion is a commercial process of many years standing, the relationships between the pressure applied to the ram, and the pressure exerted by the extruding metal on the die, mandrel, or core have not been sufficiently investigated to be thoroughly understood. From data at hanc, 
it is expected that 30,000 to $60,000 \mathrm{psi}$ will be applied on the billet in the Watson-Stillman press to extrusion-clad a core; this is a small fraction of the 2750-ton capacity of the press. From a few experiments at BMI and at Moczik Tool and Die Co., it can be rationalized that the corresponding pressure on the nickel-plated core in the welding chamber is 5000 to $7000 \mathrm{ps} 1$, and that the bulk of the applied pressure is required to overcome the friction of the flowing aluminum against itself, against the container walls, and through the porthole orifices.

In order to extrude a trailing end plug integrally bonded to the core and sheath, one simply continues to extrude aluminum after the clad core has emerged from the die. It is not difficult to determine empirically how much billet is required to clad a core, and how much longer the billet must be to provide the required end plugs. In practice, it is easy to see where the clad core ends and the end plug begins, because the coefficient of thermal expansion of aluminum $\left(24 \times 10^{-6}\right.$ in $\left./{ }^{\circ} \mathrm{C}\right)$ is greacer than that of uranium $\left(17 \times 10^{-6}\right.$ in $\left./{ }^{\circ} \mathrm{C}\right)$, so the all-aluminum end plug upon cooling shrinks more than the thinly clad core. Experience indicates that on an extrusion-clad core 3.220 inches wide by 0.240 inch thick, an integrally extruded end plug will be about 3.212 inches wide by 0.235 inch thick, with no deterioration of the bond between end plug and core or sheath.

In order to extrude a leading end plug, one begins to extrude aluminum before forcing the nickel-plated core into the flow of aluminum. Once the aluminum has come into contact with the core, the extruding aluminum draws the core continuousiy with it when the Battelle design of mandrel tip and die is employed; this type of extrusion cladding has been called the "self-propelling core method" as distinguished from the "pushed core method" employed less successfully by Battelle, in which design it is required that the core be pushed continuousiy during the cladding operation. For several reasons, particular to avoid complications in synchronizing independent pushing mechanisms, it is desirable to have self-propulsion of the core. This seems best realizable by using inserts of steel or of an aluminum alloy dovetailed into the leading end of the core, so that these will protruce sufficiently from the mandrel tip to become clad by the aluminum and thereby to ensure self-propulsion of the core. Battelle is presently working on several configurations of inserts and core-ends to determine the most satisfactory of the presentiy planned approaches. The two most interesting plans are sketched in Figure 11.

It is planned initially to extrusion-clad one core, complete with end plugs, per billet of aluminum. With experience, however, this plan may be changed to produce two or more clad cores per billet. The extrusion cladding 
rate is planned initialiy to be between four and ten feet per minute. The cladding rate being used at Battelle at this writing is one-half foot per minute, and will continie to be held at this rate during studies of the leading end plug design. It is not considered desirable to change the rate during this study. It is expected, however, that data will be available from Battelle by July 30 on the relationship between bond strength and cladding rate for the same die. The only other experience that is presently avaliable to rely on is that of Chalk River, who found bond strengths of $2000 \mathrm{ps} 1$ to 5000 psi at an extrusion cladding rate of 22 feet per minute, versus strengths of 8000 psi to 12,000 psi for a cladding rate of 8 to 10 feet per minute. Their die design, however, was sufficientiy different from Battelle's that one cannot extrapolate the present Battelle 27,000 psi at one-half foot per minute to a low figure at a higher cladding rate. It should be possible to increase considerably the cladding rate with a relatively small change in average bond strength.

In order to use the Watson-Stillman press without modifying the existing hydraulic cylinders at approximately ram level between the container and die-head, and since these cylinders may interfere with extruding at a right angle within the horizontal plane, it may be necessary to tilt the extrusion downwards about $15^{\circ}$ from the horizontal, so that the incomins core on its run-in table will pass over one of these cylinders, and the clad core on its run-out table w111 pass under the cylinder on the other side of the press. This would involve twisting the L-shaped container about $15^{\circ}$ on its up-and-down axis (as $L$ is typed on paper) in order correspondingly to depress the tip at the lower right. Such an arranzement would in no way affect extrusion cladding, but might be aesthetically undesirable. The ground rules reasonabiy exclude modification of these cylinders; in a production line, the position of the cylinders on a new press would be specified to provide against any interference, and a different type ôे press would be used.

5. Extrusion Cladding

Process

The extrusion tools, namely, the container, die block, die and mandrel tip, are heated in position by embedded Calrods to $1025-1050^{\circ} \mathrm{P}\left(552-566^{\circ} \mathrm{C}\right)$. The billet is preheated in a separate furnace to $1025^{\circ} \mathrm{F}\left(552^{\circ} \mathrm{C}\right)$.

The die housing and core preheat furnace are purged with argon. A flow of argon is maintained through the system during extrusion. The flow necessary to prevent oxidation of the core will be determined exper:mentally when the equipment is in lise. 
The billet is inserted in the container, and the ram, with attached dumm block, is advanced. Alunum is extruded until the portholes of the manarel tip are filled, but no aluminum is in the die.

The core is placed on the entrance transier table, moved into the preheat furnace and die block, and positioned in the mandrel tip. When no aluminum is in the die, a steel plate inserted through the exit side of the die will serve as a stop in positioning the core. The core pusher is then engaged to grip the plate and hold it flush with the mandrel tip slot.

The core is allowed to preheat for about 3 minutes prior to extrusion to attain a temperature of $975^{\circ} \mathrm{F}\left(525^{\circ} \mathrm{C}\right)$. The preheat time will be dependent upon the jeating equipment used and will be determined when the equipment is avallable.

Pressure is applied to the billet using experimentally determined ram speeds corresponding to plate speeds of 4 to 10 feet/minute. The optimum plate speed will be dependent upon the length of plate which is preheated. With the core in the mandrel slot a solid aluminum end plug is extruded; the core pusher holds the plate against the back extrusion pressure. When the desired length of end plug has been extruded the core pusher forces the plate into the die where it is enveloped by the flowing aluminum. A bond is formed between the nickel-plated core and the aluminum at the die opening, and the clad plece is propelled through the die with the extruding aluminum. Shaping of the core end may facilitate plck-up of the core by the extruding aluminum.

The pusher mechanism releases the core as the latter enters the die.

As the first core passes through the die block a second core is held lightiy against the trailing end of the first, and is stopped in the mandrel slot by the extruding aluminum. As the second core stops it is immediately gripped by the core pusher to prevent back extrusion into the mandrel slot.

When the trailing end of the first core has passed through the die and an end plug has been extruded, the ram is stopped and the extruded aluminum is cut with a saw so that the clad plate may be removed with handling equipment.

While the clad plate is being removed, the second core, which has been gripped in the mandrel slot, is being preheated. This plate is then clad in the same manner as was the first.

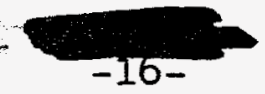


It may be found necessary to use a dummy steel follower after each core rather than using consecutive cores. is would be a shcrt length of plate used to plug the mandrel slot until the following core is preheated. It would tien be clad as a core, with a trailing end plug. When the extrusion is stopped it could be removed and the folloring core clad in the above manner.

It is not known at this time if the force required to hold the plate in the mandrel tip against the back extrusion, and to push it into the die, will cause buckling of the soft preheated core; however, precautions have been taken to support the core between the pusher and the mandrel slot so as to minimize buckling.

Since an attached dummy block is used, billets may be fed into the container continuousiy. As each billet is extruded the ram and dummy block are retracted, and a fresh billet is inserted. This operation is conducted while a clad plate is being removed and the following plate is being preheated.

When it is necessary to remove the die housing after a mu, a small steel dummy is used to plug the mandrel slot; the gate lock is released and the aluminum butt and die block are pushed out with the ram. When these have been freed from the container they are carried out through the platen with the die head, and an electric saw or a shear cuts the butt flush with the die block, leaving no gap for entrapped air. The aluminum may be left in the die housing, to be extruded out or used for cladding during the next run.

No lubricants are to be used where they might come in contact with the core or the aluminum. These areas include the I.D. of the container, the dummy block, billet, ports, mandrel slot and working faces of the dies.

An alternate method to extruding integral end plugs is that of cladding attached end plugs. This method has proven satisfactory using machined steel end plugs, but as yet $\operatorname{SAP}\left(\mathrm{Al}+19 \mathrm{~V} / 0 \mathrm{Al}_{2} \mathrm{O}_{3}\right)$ is the only aluminum alloy found which has sufficient strength at $1000^{\circ} \mathrm{F}\left(537^{\circ} \mathrm{C}\right)$ to withstand the pressures at the die tending to "pinch off" the end plug.

The core, with attached end plugs (Figure 11) is placed on the entrance transfer table, moved into the preheat furace and die block, and positioned in the mandrel tip. The leading end plug extends through the die opening approximately one-half inch to provide a means of starting the core. When the core has been heated, aluminum is extruded through the die, cladding the end plug and the core which are propelled through the tools. 
As the first plate is being clad the second, with attached end plugs, is placed on the transfer table and manually pushed to butt against the tralling end of the first. With only a light pressure maintained on the trailing plate $1 t$ will be stopped in the mandrel tip, preventing back extrusion as the extruding aluminum forces the first plate through the die. The pushing mechanism is immediately engaged to grip the entering plate, and the extrusion is stopped so that the clad plate may be removed.

When the second plate has been preheated to the desired temperature the extrusion is continued and the plate is pushed into the flowing aluminum to be clad. A short steel dummy may be used in place of the following plate to plug the mandrel slot while the following plate is being preheated or a billet is being inserted into the container. The steel dumm is extruded out with a following plate as is the normal procedure.

6. Tool Clean-Out

Tool clean-out is not anticipated after each run nor after each shift. It should be possible to reheat the tools and extrude out the remaining aluminum after periods of shutdows.

For the tools to be used with the 2750-ton press in the 320-M Building, the die block and butt will be freed by pushing the ram through the heated container. They can then be carried out by the die head. The outer shell of the die block is in two sections which fit over the tapered inner shell. Removing this outer shell permits the split inner shell to be placed in caustic to remove the aluminum from the ports and die. When this section is clean it may be opened, and the die and mandrel tip removed. These sections are to be thoroughly cleaned and inspected before reassembIy.

\section{Equipment}

The description of equipment for this process will cover only one particular installation. It is that proposed for cladding plates using the extrusion press in the 320-M Bullding. This method is not the most desirable for production use, but is an expediency in adapting a workable method to existing equipment in order to obtaln extrusion clad plates in the shortest possible time.

\section{a. Assembly}

Plates are to be clad in the 320-M Building at SRP using the 2750-ton extrusion press. The plate beins clad will travel in a nearly horizorial plane at right angles to the center line of the ram and container of the press. large circular die block, consisting of two concentric split shells designed for easy disassembly, will contain 
the mandrel tip and die, which are an adaptation of the coaxial extrusion cladding experiment which has bees developed at Battelle for short lengths of plate.

Auxiliary equipment includes an entrance transfer table with a preheat furnace and an argon atmosphere to prevent oxidation of the core, a core pushing mechanism, and a run-out taile and special handling racks to carry tire finished plates from the press.

b. Die Housing

The die housing is a cylinder of approximately 25-inch diameter by 18 inches thick, positioned between the container and die abutment of the extrusion press, as shown in Figure 14. Since a maximum of 5-1/4" clearance is avaliable between the container and the platen, the die housing will be recessed into each. These provide additional strength to resist the high bursting pressures anticlpated with the tools. To facilitate cleaning and disassembly the housing will be constructed of four sections, as shown in Figure 15. Two of these form the outer shell and two the inner shell.

(1) Outer Shell

The outer shell consists of two cylinders, $A$ and $B$, of about 25-inch O.D. with tapered internal dianeters. Keyways position the unit so that it may be passed through the die asutment with the sliding die head. Pressure from the container and ram compresses the two sections against the bolster, providing the means of sealin- the tapered inner shell, $C$ and $D$.

The cylinders are machined from Braeburn PD-2 die steel to provide the required hot hardness and toughness at temperatures up to $1100^{\circ} \mathrm{F}$. The sections must be intained at a hardness of $R_{c} 44$.

(2) Inner Sine11

The inner shell consists of a tapered cylindrical section ( $C$ and $D$ ). The taper, matched to that of the outer shell, provides a means of sealing against the intemal pressures developed during the extrusion. A tapered seal seats against the container. The mandrel tip (G), extension (F), and die (E) fit into the cavity of the split sheil.

As the billet is extruded from the container it passes through a single port of 3-1/2-inch diameter whech is then split into two 2 -inch ports desigred to feed the 
aluminum at the two flat faces of the plate. These ports turn a $90^{\circ}$ angle from the center line of the contalner so that the aluminum is flowing in the direction in which the plate will be moving. Each of the two ports feeds into a kidnez-shaped mixing chamber which in turn opens into three of the six ports of the mandrel tip.

The inner shell is machined from Braeburn T Alloy tool steel, as is the outer shell, and must be maintained at a hardness of $\mathrm{R}_{\mathrm{c}} 44$.

(3) Mandrel Tip and Guide Unit

The mandrel tip (G) and guide (F) are shown in Figure 15. This unit, with the die, is placed in the inner shell of the die housing such that each of the two mixing chambers of the inner shell feeds into three ports of the mandrel tip. This porting system is designed so as to feed aluminum around the core with a uniform flow and pressure at all surfaces.

The aluminum leaves the ports and flows over the tip of the mandrel into the final mixing chamber between the tip and the die. Here the aluminum is in contact with the core and forms a bond with the nickel under the proper time, temperature, and pressure conditions. As the bond is formed the flow of aluminum through the die carries the plate forward.

The mandrel tip is the most critical part of the extrusion tools. The six ports must provide uniform pressures and aluminum flow to tie core in order that the latter w11l be centered in tie die and subsequentiy in the sheath. The shape of the tip is important in directing the flow of the aluminum to induce "self propulsion" of the core. A tip that is not streamined ieads to high extrusion pressures and excessive forces nomal to the surface of the core; these tend to grip the core and prevent propulsion. Severe streamlining of the tip leads to a weak member which is subject to excessive deflection at extrusion pressures, with resultant pinching or restriction of the core in the slot.

Sufficlent clearance must be allowed in the mandrel slot to compensate both for the deflection of the tip and for variations in the core cross-section. If the clearance is too great, back extrusion of aluminum around the core, and restriction of the core, may result. This clearance is dependent upon the degree of streamlining of the tip, the die used, and the extrusion pressures used; Figure 16 illustrates one design which has proved satisfactory in early developments. 
It can be seen that the clearance increases from the edge to the center of the slot as does the deflection.

The plate is guided into the mandrel tip slot through a hollow cylinder ( $F$ in Figure 15) which extends through the outer shell to the preheat area. This extension is pinned for alignment of the back guide with the mandrel slot.

The mandrel and guide are made from Braeburn $T$ alloy steel hardened to $R_{c} 44-46$. This alloy has verz desirable high temperature properties.

(4) Die

The die, $E$ in Figure 15, used to form the aluminum sheath on the core, is pinned for alignment with the randrel slot. A swage bearing seems, from the data avallable, to be optimum for good bonding and for filling at the ends of a plate when extruding integral aluminum en plugs. Shear bearings require somewhat lower extrusion pressures but tend to produce poorer bonds and poorer extruded end plues than do the swage bearings. Severe swage bearings ( $90^{\circ}$ included entrance angle) are excellent in these respects but require higher pressures and show a greater tendency for back extrusion of aluminum in the mandrel slot. The slinit swage bearing is a compromise of these two types. More evaluation on the effects of sinear, swage, and radiused bearings may be advisable at a later date.

The bearing length of a die varies as the cross-section of the sheath varies, and is determined br the die maker. Minor corrections may be required of eacin new die after initial extrusions.

The die is made of Braeburn $T$ alloy steel hardered to $R_{c} 44-46$.

(5) Heating of the Die Block

The die block is heated by means of 24 cartridze-type heaters spaced around the outer shell. The total output of the heating elements is $40 \mathrm{KW}$ at 440 volts. The temperature of the block is regulated by controllers with thermocouples placed close to the die and billet areas.

The elements are removable so that the outer siell ( $A$ and $B$ ) may be separated to disassemble the cools.

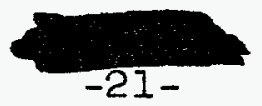




\section{DPW $-56-276$}

c. Auxiliary Equipment

The run-in table, preheat furnace, core pusher, and run-out table are in the design stage; however, a general description of these items is included in this document.

\section{(1) Transfer Tables}

The design of entrance and exit transfer tables for use with this equipment is not yet complete; however, the general characteristics which are desired will be discussed.

The entrance transfer table will be enclosed, in part, by the preheat rurnace. It should have, in addition to the bottom rollers, side and top rollers at intervals of about 2 feet to maintain alignment of the plate as it enters the die. If possible, the side and top rollers should be hinged, as a unit, to the bottom roll section to facilitate removal of a jamined or buckled plate from the die.

The rolls of the lower section should be spaced at close intervals of 3 to 4 incres to prevent sagging of the core, when it is stationary and at temperature.

The end of the transfer table nearest the die should fasten to the pusher mechanism which in turn will be fastened to container, or some section of the press, for rigidity.

The run-out tables need only to supply support and a guide for the plate as it leaves the die.

\section{(2) Preheat Furnace}

The preheat furnace will serve to heat the core and to contain the inert gas atmosphere. Calrod-type heating elements will be interspersed with, or around, the rollers of the run-in table. The furnace is to be in sections so that the length of core which is preheated may be varied. Initially, the entire core will be heated; as the program continues it is hoped that the furnace may be shortened so that the core will be heated as it passes through a section adjacent to the die housing. The core pusher will also be inclosed by the furnace in this area. Inlets for the inert gas should be provided on each section of the furnace.

\section{(3) Core Pusher Mechanism}

This unit will be essentially two flat shoes which will be driven so as to grip the plate on the wide faces to hold it positioned in the mandrel tip. A forward

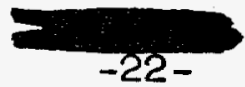




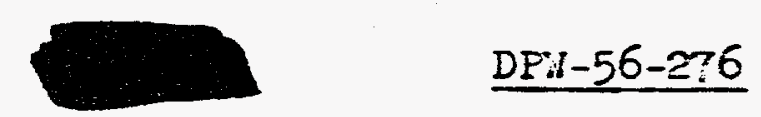

stroke of about 1 inch will push the core into the die where it will be released by the pusher and propelled by the flowing aluminum.

The shoes will be of sufficient area to prevent deformation of the plate. Although the shoes will be in the heated zone, the drive mechanisf be located outside of the furnace. The shoes 111 be placed as close to the die housing as is possible in order to minimize the tendency for buckling of the heated core.

A reverse stroke will be provided to aid in pulling back any cores which may become jammed in the mandrel tip.

8. Extrusion Clad Cores

The specifications for the extrusion-clad plates follow:

a. Outer Ribbed Plate (F1gure 1)

Length of clad core 162 inches $\pm 1 / 2$ inch

Length of end plugs Not firmed up; minimum 2 inches, maximum 5 inches.

Overall length of clad 172 inches $\pm 1 / 2$ inch max. core and end plugs.

Width (bevel)

2.850 inches $+.810^{n}$

Thickness (away from ribs)

Rib height ( 2 sets)

Overall thickness Min. 0.587
Plain Unribbed Plate (Figure 3)

0.240 inch $\pm 0.008^{n}$

0.150 inch $\pm 0.007^{n}$

0.200 inch $\pm 0.007^{\circ}$

b. Plain Unribbed Plate (Figure 3)

Length of clad core

Lenfth of end plugs

162 inches $\pm 1 / 2 "$.

Overall length of clad core and end plugs.

Not firmed up; min. 2"; $\max .5^{\prime \prime}$

Width (bevel)

172 inches $\pm 1 / 2^{\prime \prime}$ maxiswur.

Thickness

3.160 inches $+.010^{\prime \prime}$

0.240 inches $\pm 0.008^{\prime \prime}$ 
9. Testing and Straightening

The fintshed plates are inspected for dimensional tolerances, and tested nondestructively for bond continuity, sheath quality, and soundness of end closure. Bond continuity is reasured by means of ultrasonics. The soundness of the end closure and the location of the ends of the core are revealed by fluoroscopy or X-radiography. The quality of the sheath is determined by visual inspection for surface defects, spot tests for contamination and residual cladding thickness, and by autoclaving the plates at $175^{\circ} \mathrm{C}$ for 48 hours in saturated steam at $125 \mathrm{psi}$. It is recommended that the plates be autoclaved in the vertical position.

Straightness specifications are as follows: (1) camber: less than $1 / 2$ inch in 15 feet; (2) bow: less than 1 inch over 15 feet or less than $1 / 4$ inch over any 1 foot length. The plates should be straightened, if necessary, by gag pressing before autoclaving. Then when the plates are transferred to the vertical position for autoclaving, the straightness can be remeasured.

A final visual inspection of the surface of the plate should be made after autoclaving.

10. Reject Plate Recovery

Aluminum is removed from reject plates by etching in a solution of $\mathrm{NaOH}$ and $\mathrm{NaNO}_{3}$. The nickel electroplate is then removed with $\mathrm{HNC}_{3}$. The stripped plate is either recycled to the plating operation or is scrapped, depending on dimensional tolerances and surface quality. With the extrusion cladding process, it will be possible to use plates with 10 mils thinner claddins than has been considered safe or practical for the other processes. Consequently, rejection will be for other causes than thinness of cladding.

11. Waste Solutions

Waste solutions that contain uranium are neutralized and filtered to recover the uranium. These operations are similar to those in use in 313-k Building, except that phosphoric and hydrochloric acids are present, and the anodic etch solution mist be oxidized with $\mathrm{H}_{2} \mathrm{O} 2$ before neutralizing, in order to prevent formation of an unfilterable precipitate.

\section{Process Data}

The operations required for extrusion cladding plates are siver in the following flow sheet. Based on experience with step-pressclad plates, and on judgment about the probable performance of extrusion cladding, rejects should be Iimited to $10 \%$ of 
as-received cores. Half of this, or 5\%, should be reclaimable because 2 widths are required, so excessively wide plates can be machined to the tolerances of one or the other of the two widths.

An additional $2 \%$ of the cores may be rejected for nickel electroplating defects, of which half should be reclaimable by stripping. This brings the cumulative total oi rejects to $6 \%$.

A further $3 \%$ rejection of extrusion clad plates for a variety of causes (voids at end plugs, uncentered cores, boxing during cladding) may be experienced, of which hal: should be salvageable by stripping and reprocessing.

The maximun rejection of fuel plates through fabrication should therefore ce limited to 7-1/2\% for all causes and tise yield should correspondingly be $92-1 / 2 \%$.

WJOL/Jss 
ITEM

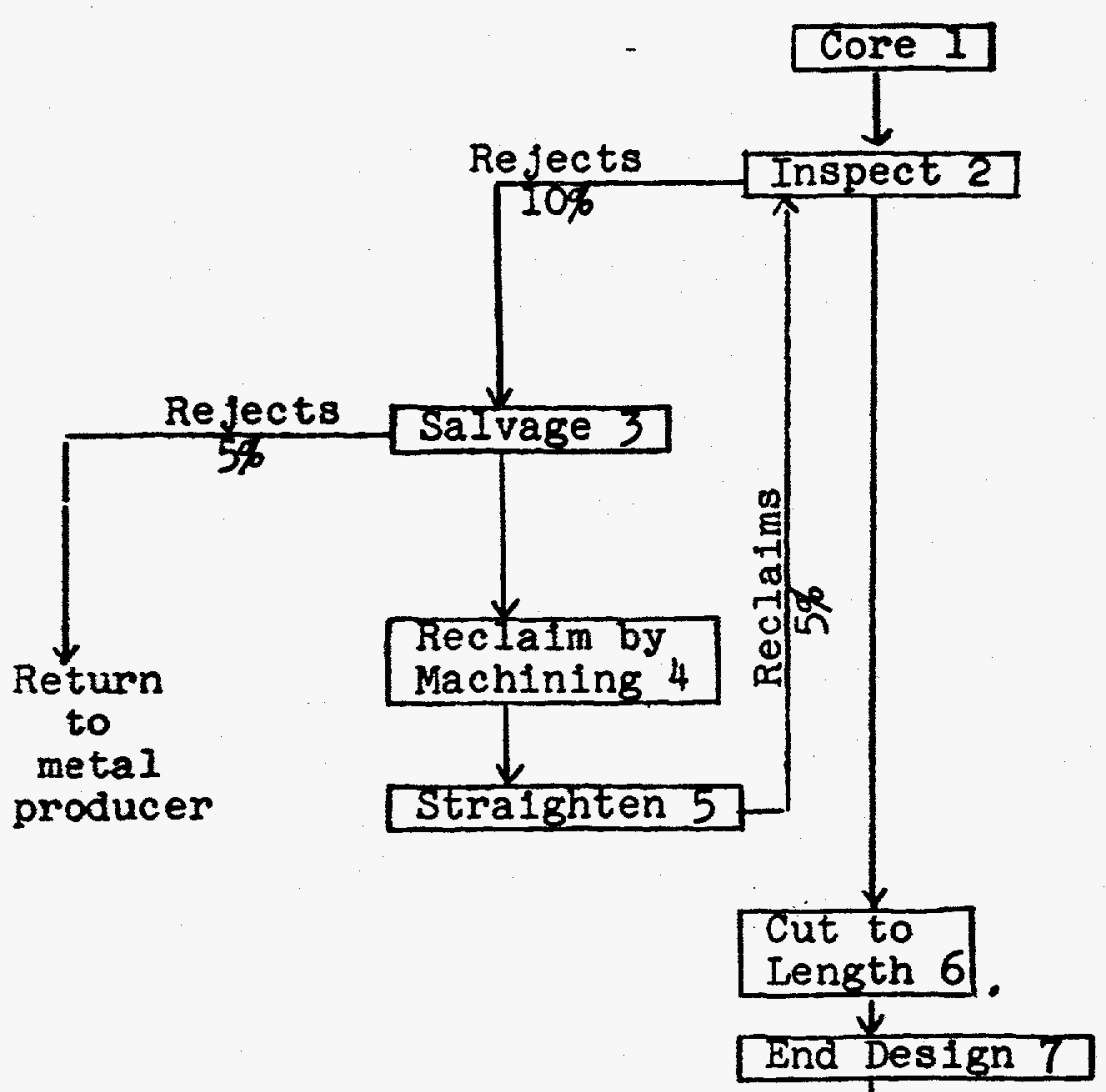

Return

to metal producer

\section{REMARKS}

1. Heat treated and finish machined.

2. We1gh for accountability. Measure length, 2 widths, thickness. Examine surface. Examine for beta transformation. Measure bow, camber.

3. Reject untransformed plates. Re ject thin plates<0.176". Re ject narrow plates< $2.455^{\prime \prime}$. Reject heavily pitted plajes.

4. Machine wide plates to size. Machine underwidth center plates to outer plate size.

5. Resistance heat while stretch straightening plates that are not within tolerances.

6. Cut to $13^{\prime} 6 \pm 1 / 2^{\prime \prime}$

7. Machine dovetails on both ends (shape and dimensions depender on data forthcoming from BMI).

8. Inspect for dimensions of dovetall, finish.

9. Store in air conditioned moom.

10. Use channel to prevent bending in transfer.

11. Trichlorethylene, 3 minutes.

12. $35 \%$ to $50 \% \mathrm{HNO}_{3}$, room temp.,

13. Cold process $\mathrm{H}_{2} \mathrm{O}, 1$ minute.

14. Solution - $60 \mathrm{gals} \mathrm{H}_{2} \mathrm{O}$, 40 gals. $\mathrm{H}_{3} \mathrm{PO}_{4}(85 \%){ }_{2} \mathrm{gals} . \mathrm{H}$ Room temp., 4 min. at 80 angs $/ \mathrm{ft}$ or $10 \mathrm{~min}$. at 40 amps $/ \mathrm{ft}$ ?

15. Cold process $\mathrm{H}_{2} \mathrm{O}, 1$ minute 16. $40 \%$ to $50 \% \mathrm{HNO}_{3}$, room tem., 2 minutes 

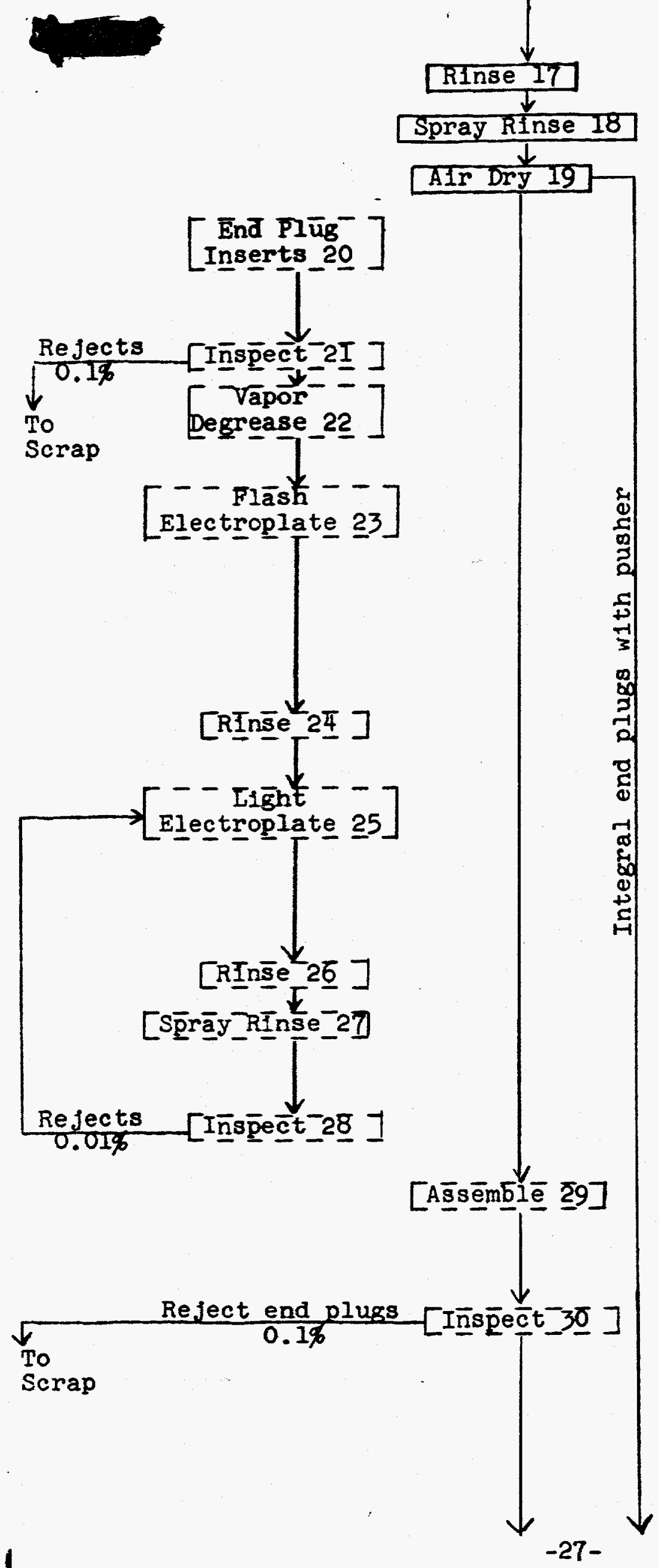

17. Cold process $\mathrm{H}_{2} \mathrm{O}, 1$ minute.

18. Cold defonized $\mathrm{H}_{2} \mathrm{O}$.

19. Forced dry air, $70^{\circ}-80^{\circ} \mathrm{C}$ to remove molsturé, 1 minute.

20. SAP plug machined to fit dovetail slots in core (shape and dimensions dependent on data for forthcoming from BKI

21. Inspect for dimensions.

22. Trichlorethylene, 2 minutes

23. Chemical make-up 1b/100 gal.

CuCN . . . . 33

$\mathrm{NaCN} \cdot . \cdot 41$

$\mathrm{Na}_{2} \mathrm{CO}_{3} \cdot \therefore 24$

Rochelle salt . . 48

$40^{\circ}-45^{\circ} \mathrm{C}, 30 \mathrm{amp} / \mathrm{ft}^{2}, 1 \mathrm{~min}$. This is to deposit about 0.01 mil of copper in order to facilitate later nickel plati for bonding.

24. Cold process $\mathrm{H}_{2} \mathrm{O}, \mathrm{I}$ min.

25. Nickel flash. Use solution of Item 31 at $35^{\circ} \mathrm{C}, 5 \mathrm{~min}$. at $16 \mathrm{amp} / \mathrm{ft}^{2}$. This is to depos about $0.05 \mathrm{mll}$ nickel over th copper, to prevent a copperuranium interface at the dovetall joint.

26. Cold process $\mathrm{H}_{2} \mathrm{O}, 1 \mathrm{~min}$.

27. Cold deionized $\mathrm{H}_{2} \mathrm{O}$

28. Inspect for complete coverage of copper on dovetail by nick Do not store over 2 days befo cladding.

29. Handle with clean dry gloves. Use cloth padded arbor press assemble dovetailed joint at both ends of core.

30. Inspect for fit of dovetail, concentricity of core and end plugs 
31. Chemical make-up $\frac{\mathrm{P}-5 / 100 \mathrm{gal}}{\text { (bs/10 }}$ $\mathrm{N} \mathrm{SO}_{4} \cdot 6 \mathrm{H}_{2} \mathrm{O}$.... 58 . $\mathrm{Na}_{2} \mathrm{O}_{4} \cdot 7 \mathrm{H} \mathrm{O} \cdot . .133$ (or $\mathrm{MgSO}_{4} \cdot 7 \mathrm{H}_{2} \mathrm{O}$ )

$\mathrm{NH}_{4} \mathrm{Cl}^{4}: \therefore: \therefore 12.5$

Attibated carbon:. 5

$\mathrm{H}_{2} \mathrm{O}_{2} 30 \%$. . I pir $35^{\circ} \mathrm{C}, 40 \mathrm{mIn}$.at $16^{\circ}$ amps $/ \mathrm{ft}^{2}$ or $20 \mathrm{~min}$. at 32 amps $/ \mathrm{ft}^{2}$. This will deposit $0.4 \mathrm{mil}$ nickel for bonding.

32. Cold process $\mathrm{H}_{2} \mathrm{O}, 1$ minute.

33. Cold delonized $\mathrm{H}_{2} \mathrm{O}, 1$ minute.

34. Hot delonized $\mathrm{H}_{2} \mathrm{O}, 70-80^{\circ} \mathrm{C}$.

35. Forced dry a1r, $70-80^{\circ} \mathrm{C} ., 1 \mathrm{mir}$

36. Inspect for plating defects.

37. Use polythene wrap and metal channel to avold bending and damage to electroplate. Do not store more than 2 days after plating. If obliged to store over 5 days, Canadians rub with steel wool before cladding.

38. 2S or M-329 aluminum, furnished to size.

39. Skin cut by dry. machining to remove possible surface contaminants.

40. Inspect for dimensions, cleanliness, gross inclusions,

41. $1000^{\circ} \mathrm{F}\left(538^{\circ} \mathrm{C}\right)$ in billet furnace, 10 minutes.

42. From Moczik Tool and Die Works

Tools 42

(containers, dies)

Preheat 43

43. Initial preheat to $1000^{\circ}-1050^{\circ}$ $\left(538^{\circ}-566^{\circ} \mathrm{C}\right)$.

Argon 44

Flush Plate Preheating Furnace 45

44. Tank gas.

45. Continuous flush of preheat furnace on run-in table. 


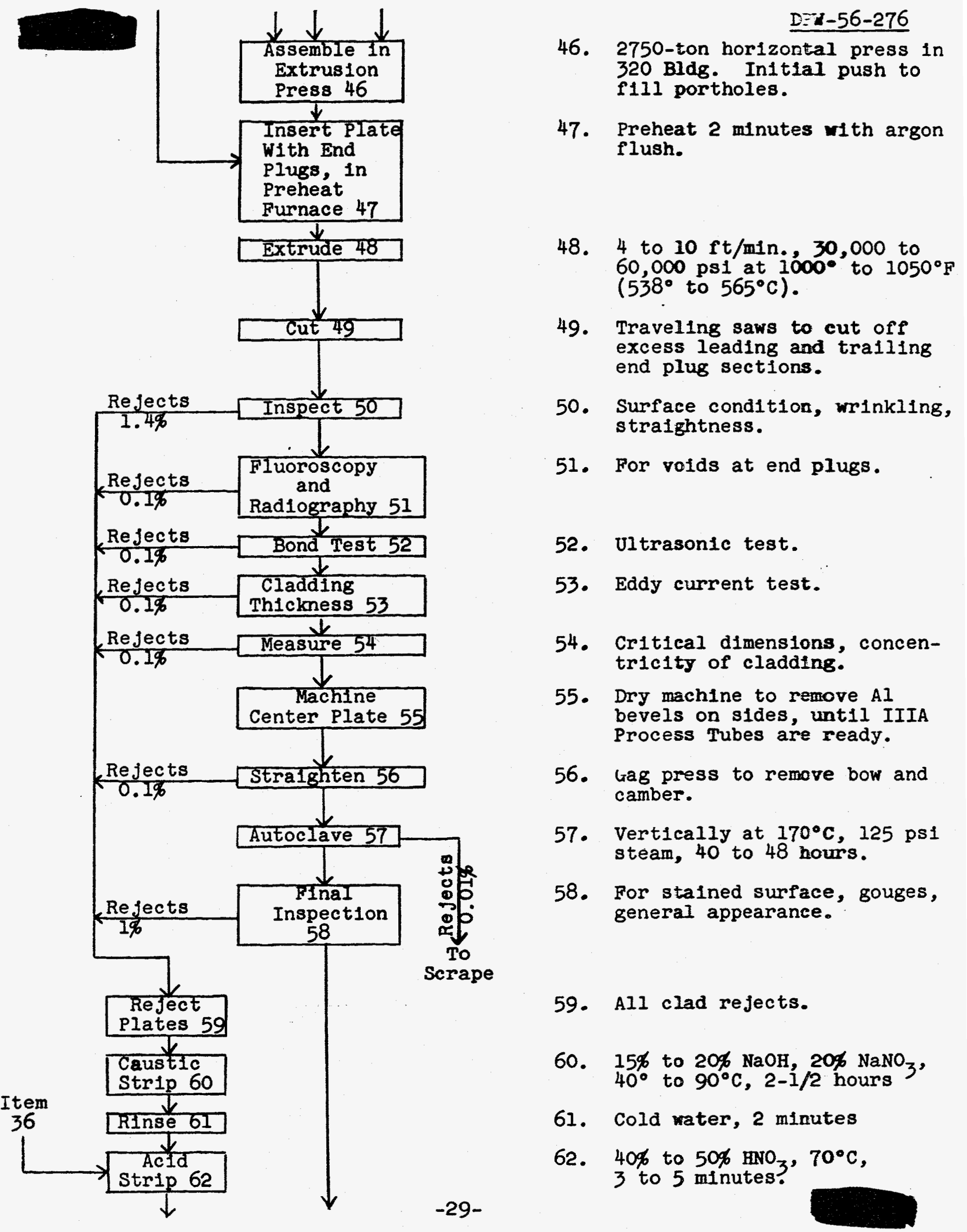



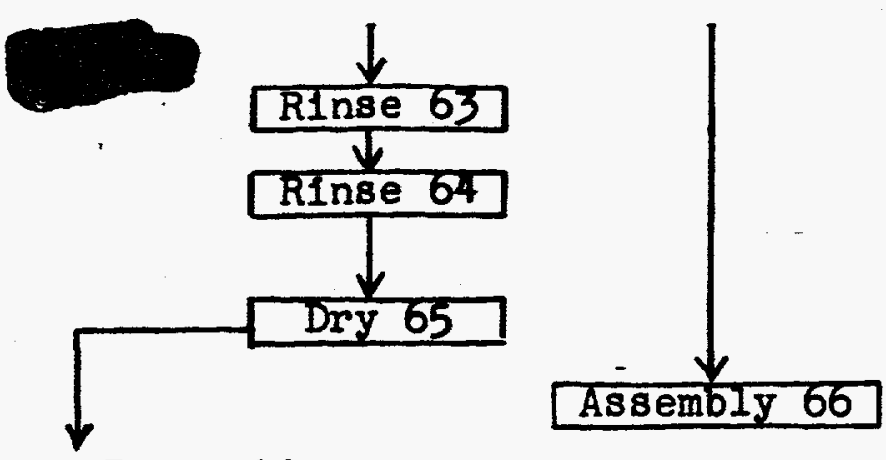

To Inspection,

Item 2

63. Cold water, 2 minutes.

64. Hot water, $55^{\circ}$ to $65^{\circ} \mathrm{C}$, I-minute.

65. Forced dry air.

66. "B" Process Tubes, aluminum shims, top and bottom fittins 


\section{FIGURE 1}

\section{CROSS SECTION}

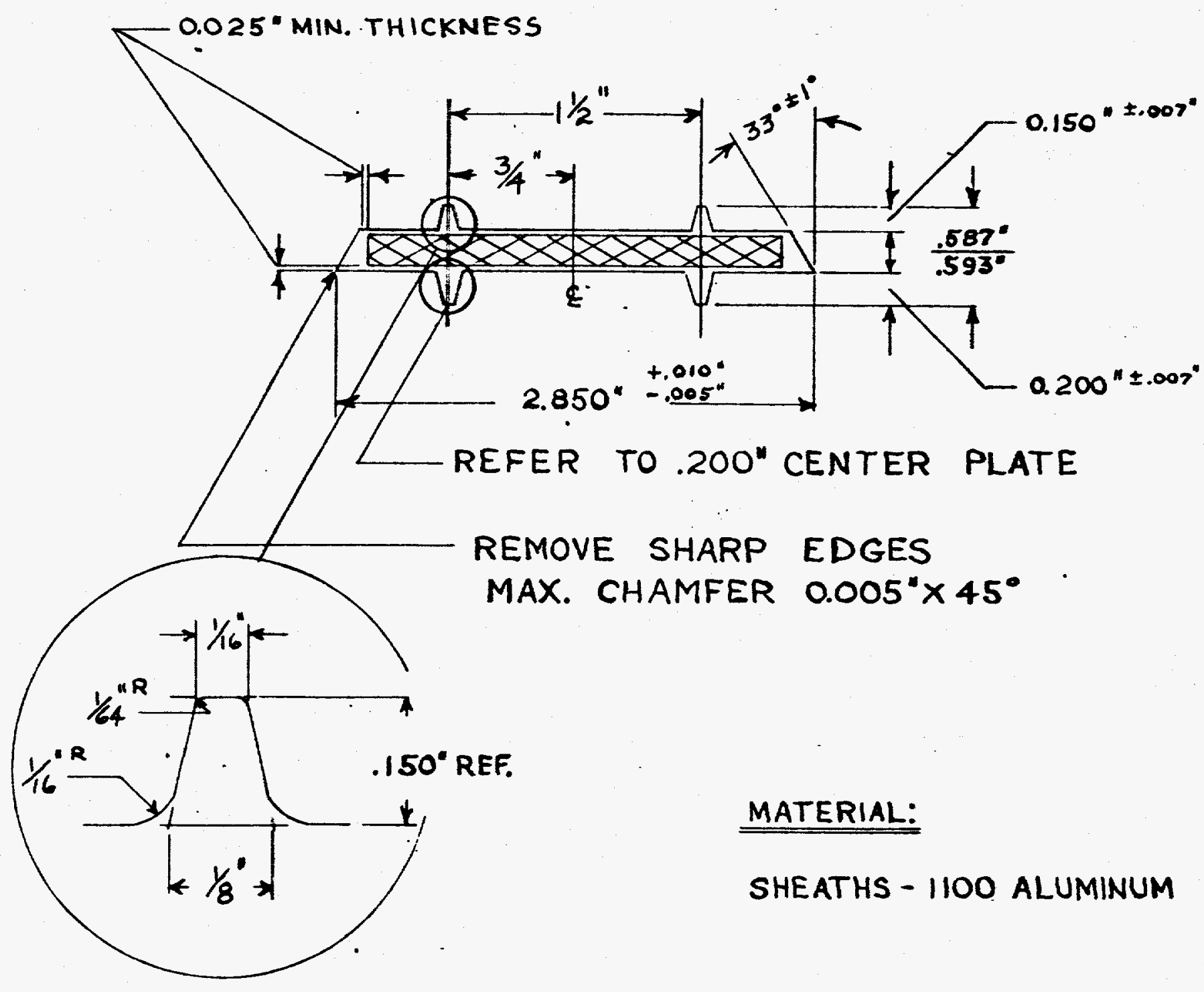

TOLERANCES

FRACTIONAL $\pm 1 / 64^{\circ}$

CAMBER 1/32" PER FOOT OF LENGTH

BOW $1 / 32^{\circ}$ PER 2 FEET OF LENGTH

\section{OUTER PLATE}


FIGURE 2

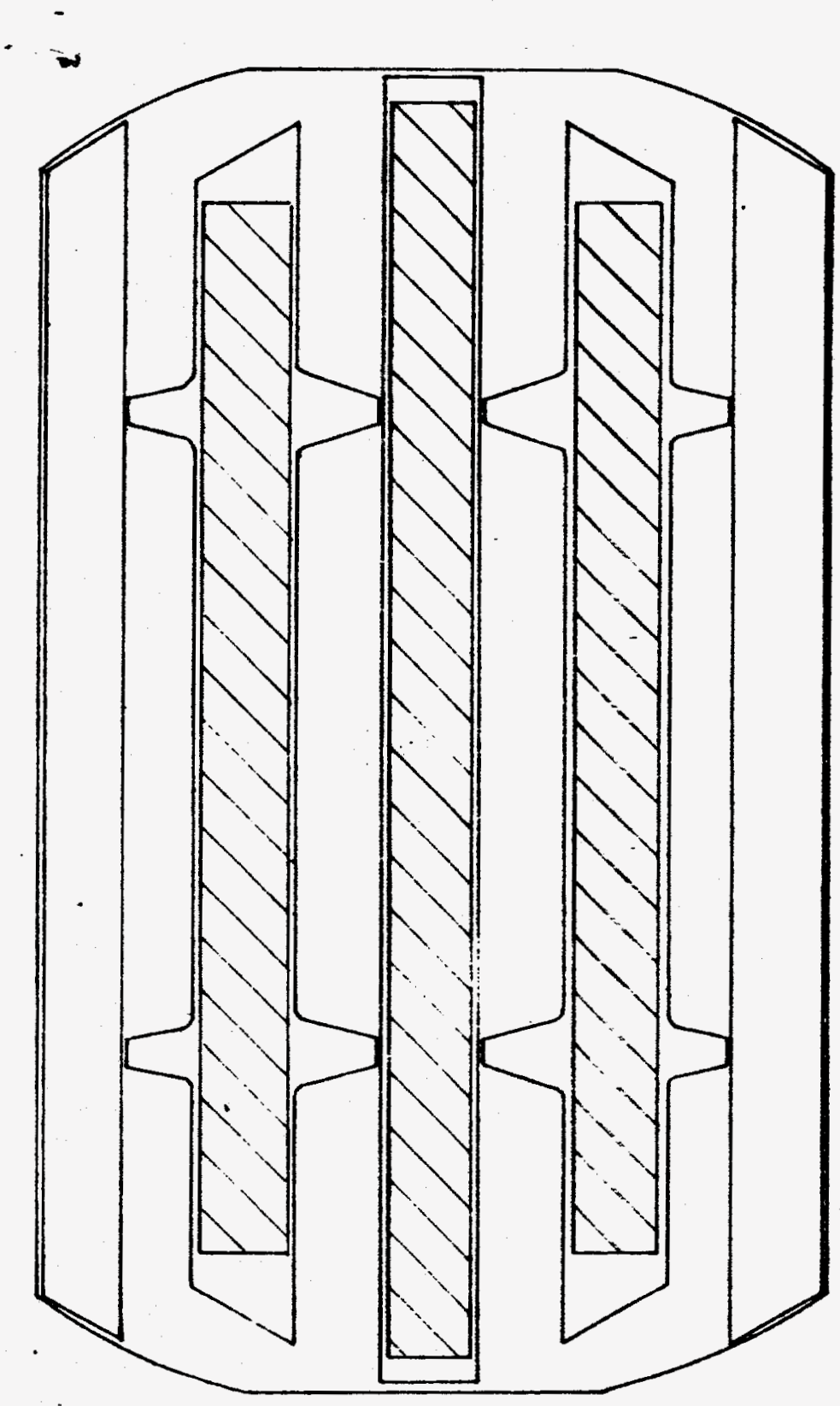

ASSEMBLY

MARK III-A PLATES IN

MARK III PROCESS TUBE

SCALE: $2^{\prime \prime}=1^{\circ}$ 


\section{FIGURE 3}

\section{CROSS SECTION}

0.025 "MIN. THICKNESS

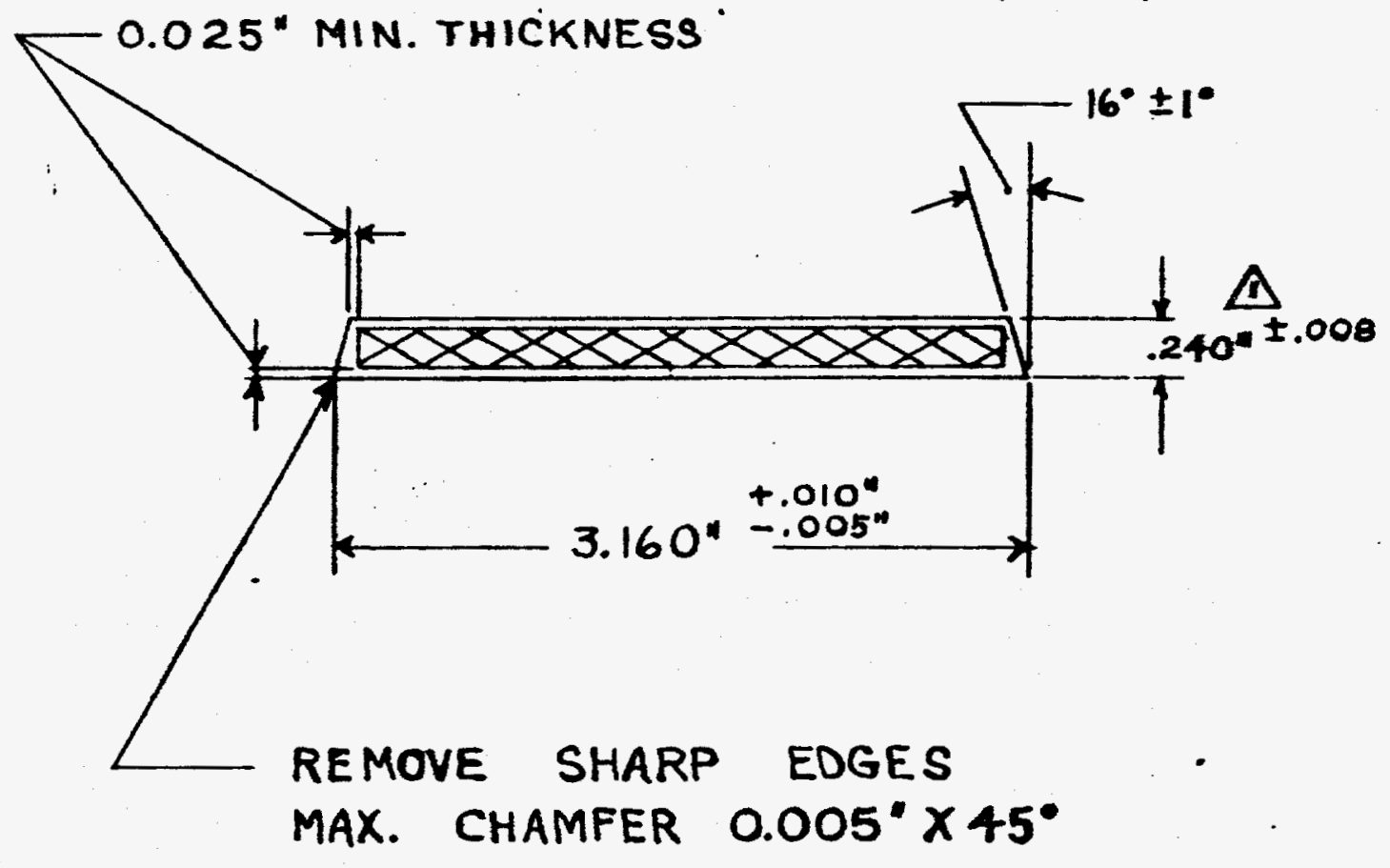

MATERIAL:

SHEATH - INOO ALUMINUM

\section{TOLERANCES}

FRACTIONAL $\pm 1 / 64 "$

CAMBER $1 / 32$ "PER FOOT OF LENGTH

BOW 1/32" PER 2 FEET OF LENGTH

CENTER

PLAIN PLATE 


\section{FIGURE 4}

\section{CROSS SECTION}

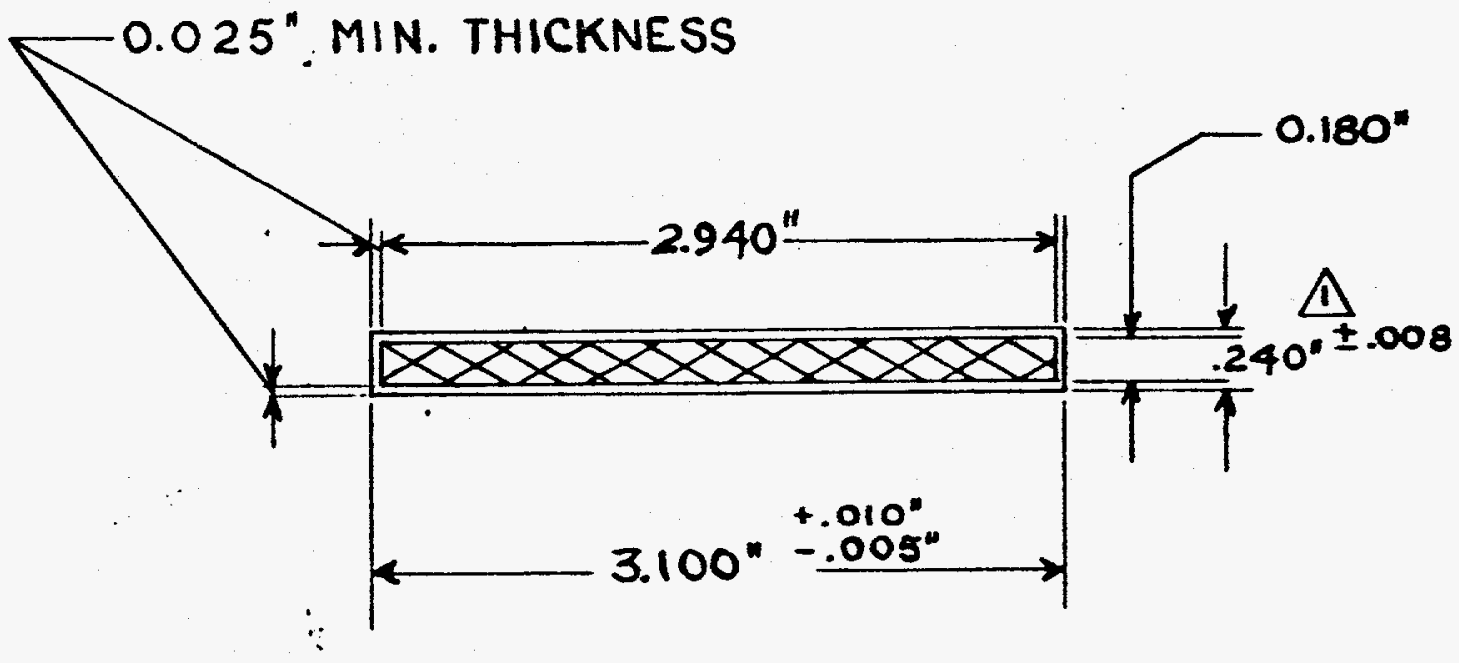

MATERIAL:

SHEATH - 1100 ALUMINUM

\section{TOLERANCES}

FRACTIONAL $\pm 1 / 64^{\prime}$

CAMBER 1/32" PER FOOT OF LENGTH

BOW 1/32" PER 2 FEET OF LENGTH

\section{CENTER PLATE}

MODIFIED TO FIT INTO

MARK III B PROCESS TUBE 
FIGURE 5

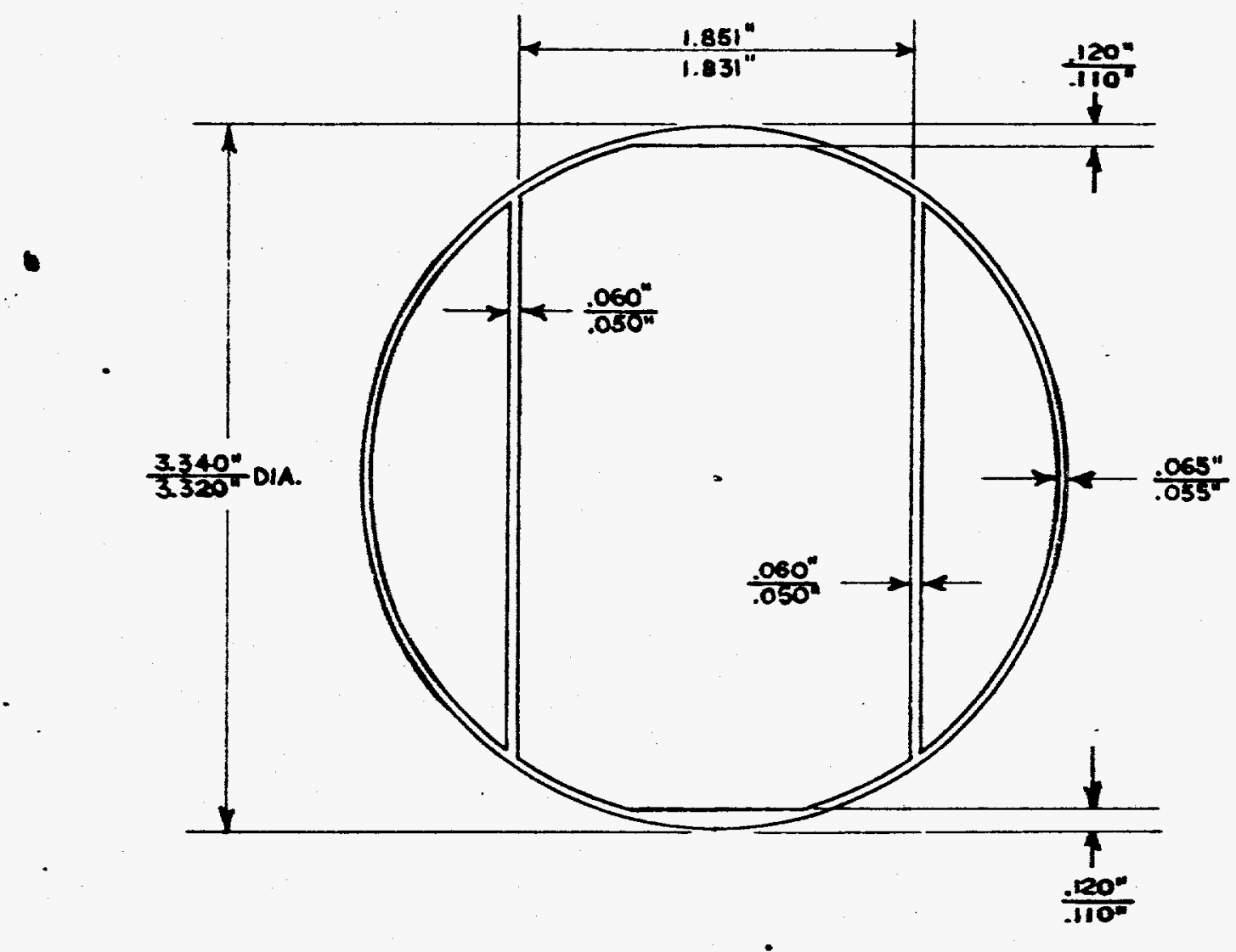

MAT'L:6063 AL.

REFERCENCE DRAWHG NO. E26830 (DUPONT ENGINEERING SKETCH

"B" PROCESS TUBE 
FIGURE 6
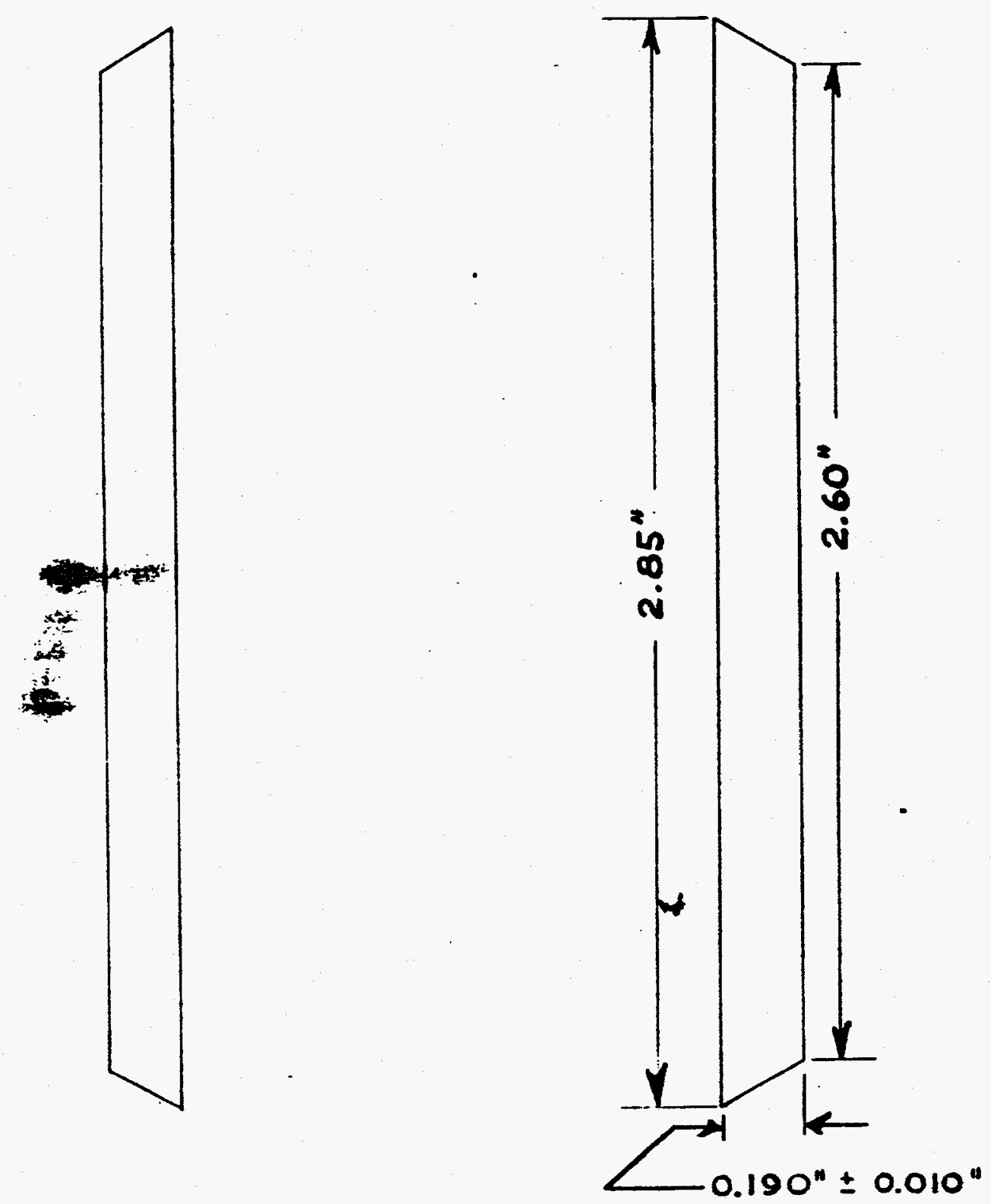

SHIMS FOR MARK III PROCESS TUBE

SCALE: $2^{n}=1^{*}$ 


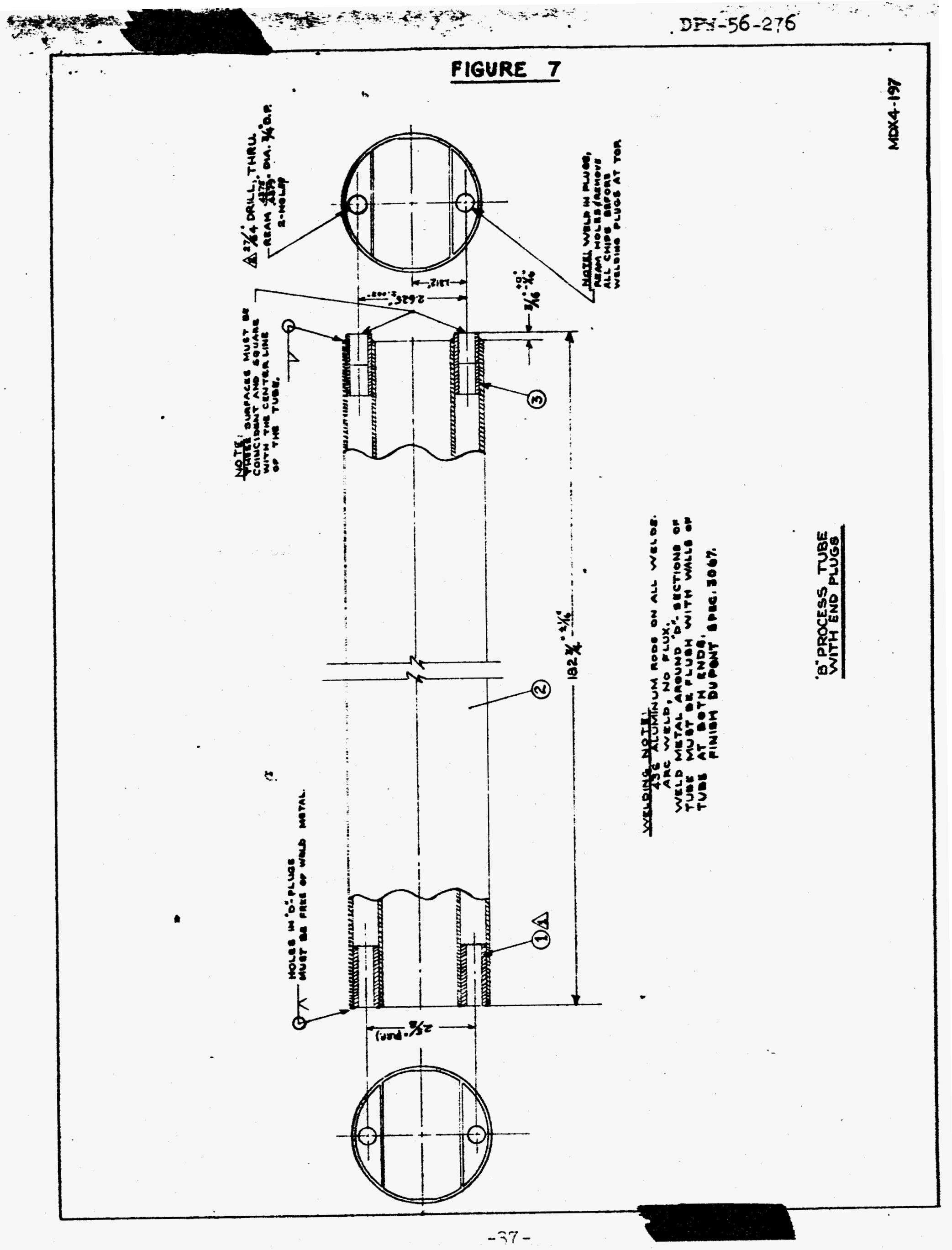


FIGURE 8

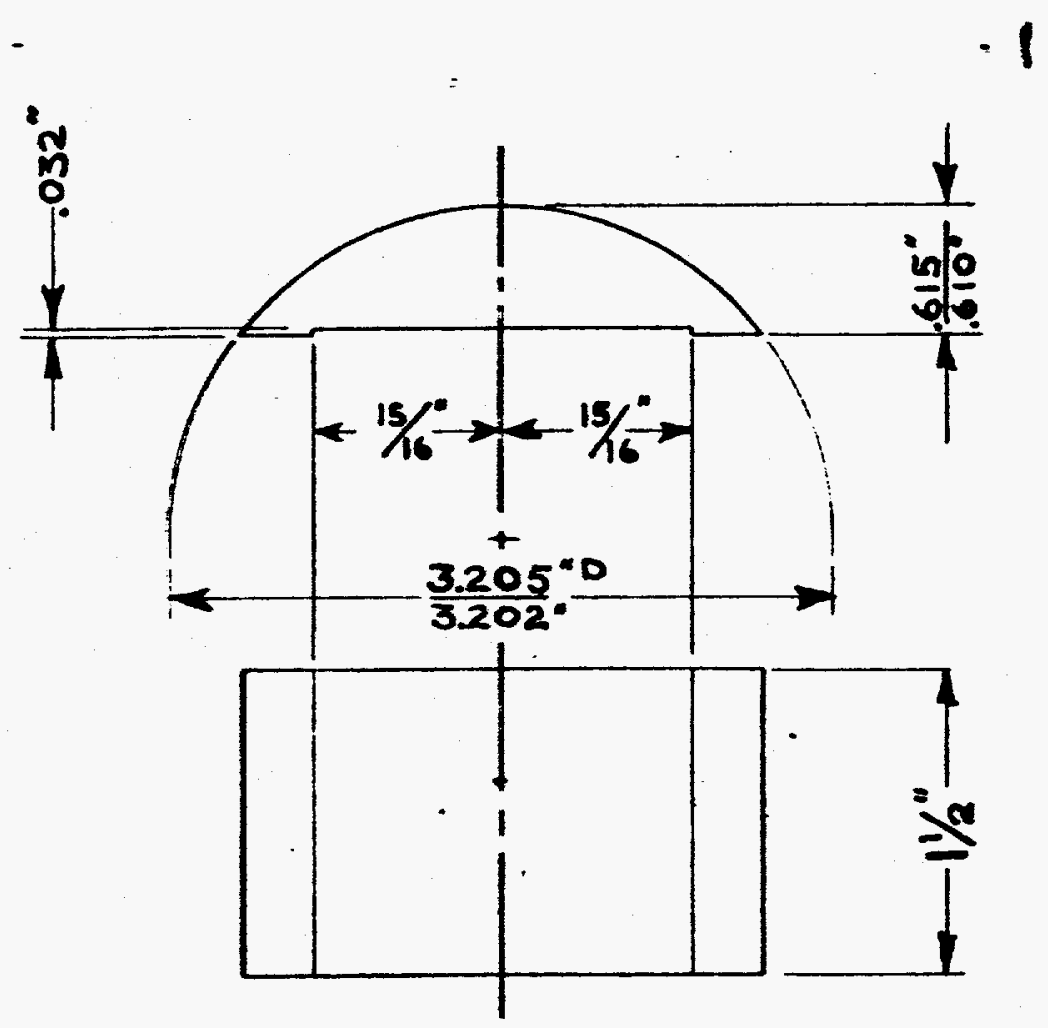

MAT'L: $635-T 6$ ALUMINUM 12S FINISH ALL OVER

\section{TOLERANCES}

ON ALL DIMENSIONE.

FROM FINISHED SURFACES

EXCEPT AS NOTED.

$$
\text { TO BE }
$$

DECIMAL $\pm .005^{\circ}$

FRACTIONAL \pm 164

\section{"D"-PLUG (BOTTOM)}




\section{FIGURE 9}

$=\frac{10}{\infty}$
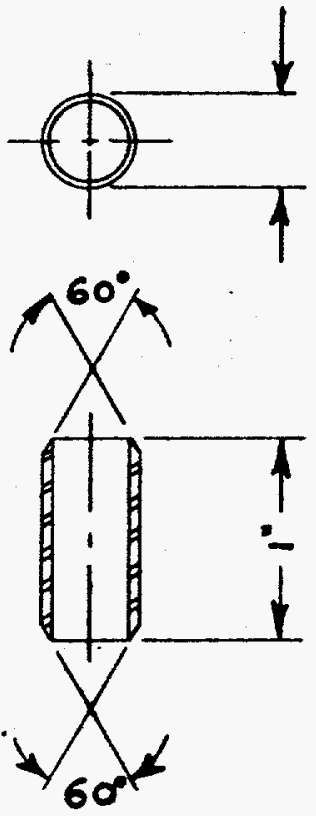

TOLERANCES

ON ALL DIMENSIONS FROM FINISHED SURFACES EXCEPT AS NOTED.

TO BE

DECIMAL $\sim$ FRATIONAL

MATERIAL: $1 / 2$ "O.D. $\times 1 / 16$ WALL 304 S.S. TUBING RE-ENTRANT TUBE 


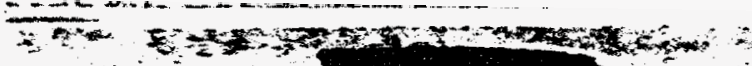

\section{FIGURE 10}

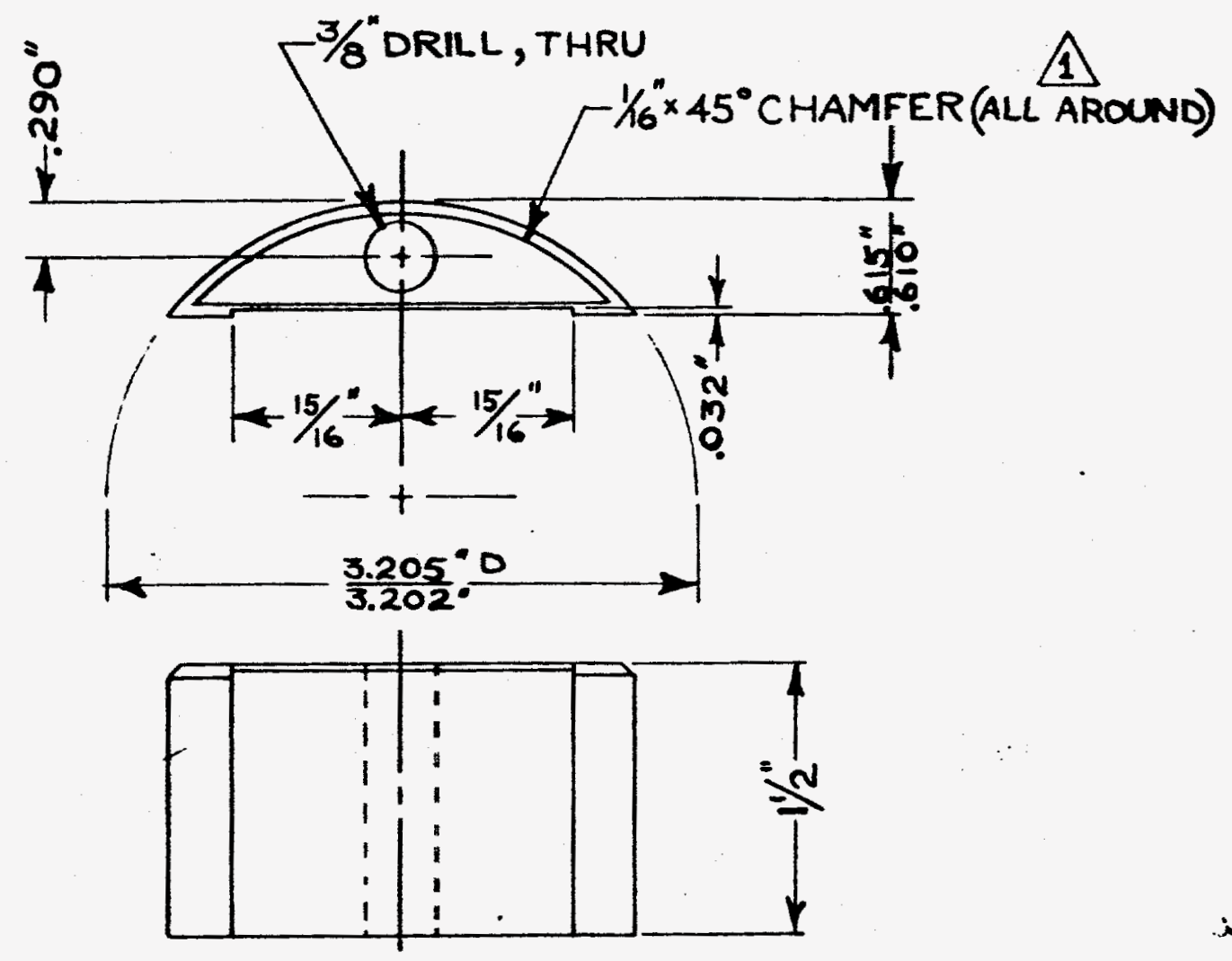

MATERIAL: $635-T 6$ ALUMINUM 125 FINISH ALL OVER

"D"-PLUG (TOP) 


\section{FIGUNE 11}

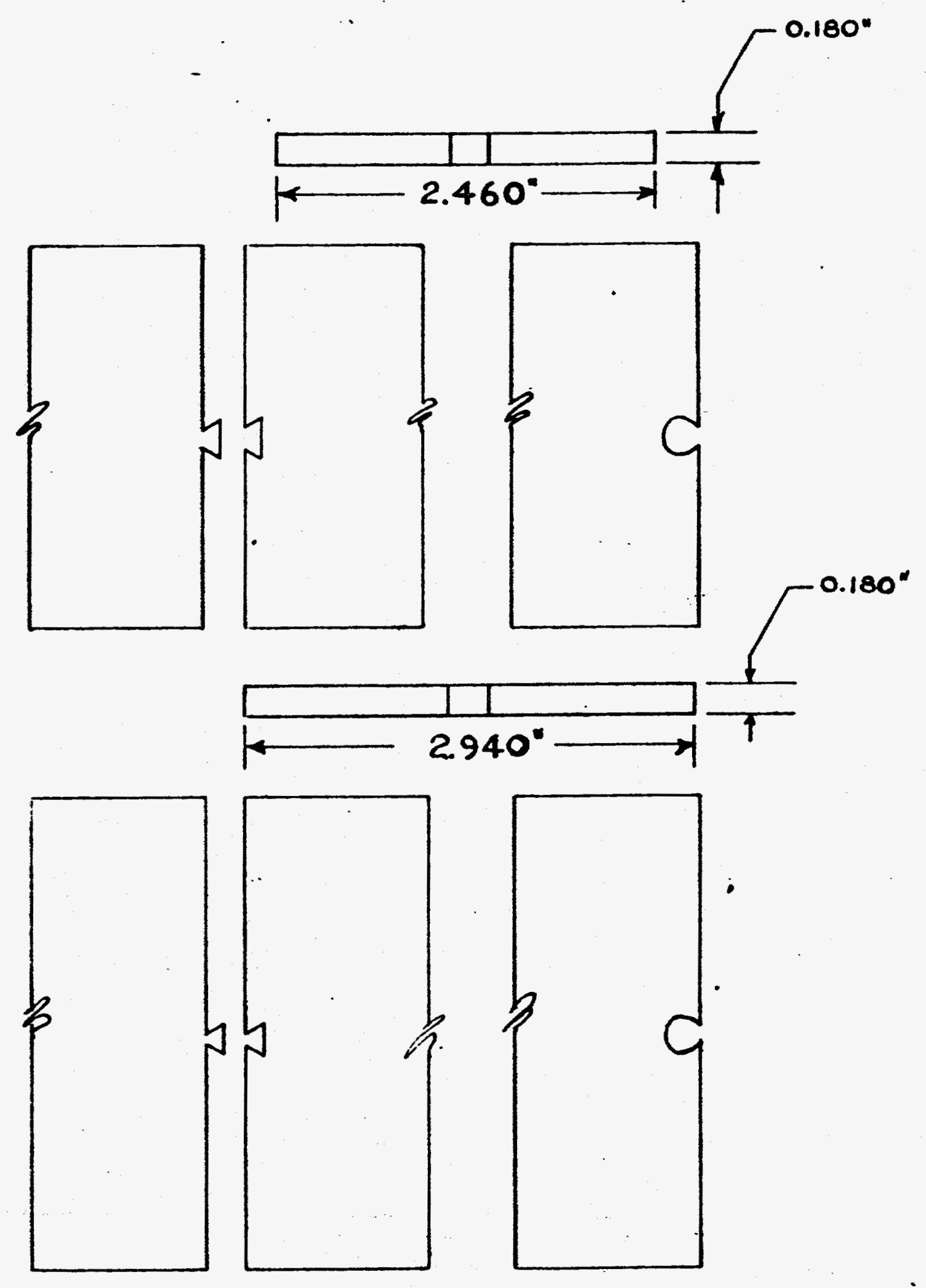

CORES \& END PLUG DESIONS 


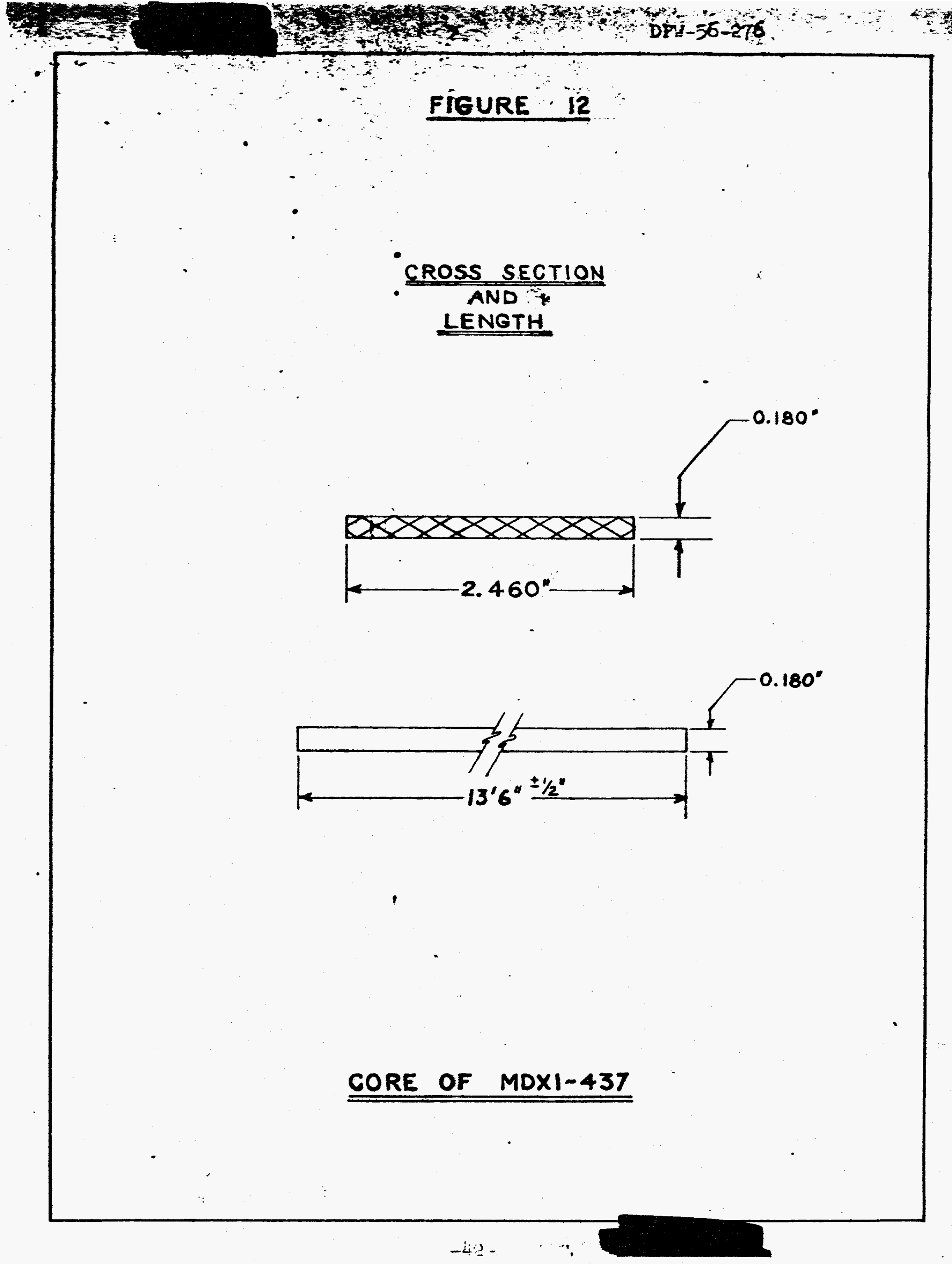


